\title{
Widespread active seepage activity on the Nile Deep Sea Fan (offshore Egypt) revealed by high-definition geophysical imagery
}

\author{
Stéphanie Dupré ${ }^{a, b,{ }^{*}}$, John Woodside ${ }^{a}$, Ingo Klaucke ${ }^{c}$, Jean Mascle ${ }^{d}$ and Jean-Paul Foucher ${ }^{b}$ \\ a Sedimentology and Marine Geology Department, Faculty of Earth and Life Sciences, Vrije Universiteit, De \\ Boelelaan 1085, 1081 HV Amsterdam, The Netherlands \\ ${ }^{\mathrm{b}}$ Département Géosciences Marines, IFREMER, Brest Centre, 29280 Plouzané, France \\ c Leibniz Institute of Marine Sciences IFM-GEOMAR, Wischhofstrasse 1-3, 24148 Kiel, Germany \\ d Géosciences Azur, 2 quai de la darse, 06235Villefranche sur Mer Cedex, France \\ *: Corresponding author: S. Dupré, Tel.: + 332982247 09; fax: + 3329822 45 49, email address : \\ stephanie.dupre@ifremer.fr
}

\begin{abstract}
:
Fluid escape structures on the Nile Deep Sea Fan were investigated during the MEDIFLUX MIMES expedition in 2004. Mud volcanoes, pockmarks and authigenic carbonate structures were surveyed for the first time with a high-resolution deep-towed $75 \mathrm{kHz}$ sidescan sonar and a 2-8 kHz Chirp sediment echosounder. In combination with existing multibeam bathymetry and detailed seafloor in situ geological observations, these new data allowed detailed seep analyses. About 60 gas flares were detected acoustically in the water column from the sidescan sonar raw data at water depths from 770 to $1700 \mathrm{~m}$. These gas flares coincide at the seabed with 1) the centres of the mud volcanoes where mud is also extruded, 2) the borders of the mud volcanoes where the emitted gases contribute to the precipitation of authigenic carbonates, and 3) to the edges of broad sheets of authigenic carbonates. Subsurface sediments are commonly disturbed by ascending fluids throughout the delta, with an abundance of seep-related carbonate structures on the seafloor. The feeder channels below mud volcanoes, similar to the gas conduits below the widespread carbonate crust structures and pockmarks, are relatively narrow and, for the vast majority of them, do not exceed a few metres in diameter. The seeps on the Nile Deep Sea Fan clearly follow lineations on the seafloor that we can relate to faults.
\end{abstract}

Keywords: Nile Deep Sea Fan; seepage; backscatter; sidescan sonar; high-resolution; gas chimneys; mud volcanoes; authigenic carbonates 


\section{Introduction}

Seabed fluid seepage commonly occurs at active and passive continental margins where fluids are squeezed from subducting sediments and leak/migrate from deep reservoirs, as for example in the Gulf of Mexico (Sager et al., 2003), the Black Sea (Klaucke et al., 2006), the Sea of Okhotsk (Obzhirov et al., 2004), the West African Basins (Gay et al., 2003; Pilcher and Argent, 2007) and the Barbados accretionary complex (Henry et al., 1990; Le Pichon et al., 1990). The spectrum of morphologies varies from pockmarks (Hovland and Judd, 1988; King and MacLean, 1970) to mud volcanoes of various sizes (Dimitrov, 2002; Judd and Hovland, 2007); and both ends of the spectrum may be combined, for example with pockmarks forming on or around mud volcanoes (Dimitrov and Woodside, 2003).

The Egyptian margin in the Eastern Mediterranean Sea is an example of a passive rifted continental margin where fluid seepage is highly active. Geological structures that host seeps range from large fluid-rich 'gas chimneys' to pockmarks and carbonate pavements, and fields of smaller mud volcanoes associated sometimes with brines (Fig. 1) (Bayon et al., 2009; Dupré et al., 2008; Dupré et al., 2007; Huguen et al., 2009; Loncke et al., 2004). This paper presents detailed near bottom acoustic characterisation of mud volcanoes (Fig. 2) and authigenic carbonate related seeps in the deep water submarine Nile Deep Sea Fan (Fig. 1). This new dataset combines for the first time acoustic gas bubble detection in the water column (Fig. 3), seafloor backscatter and high-resolution chirp profiles (Figs 4 to 13). The data were acquired during the MIMES (Multi-scale Investigations of Mediterranean Seeps) expedition of R/V Pelagia in 2004 with a deep tow sidescan sonar (Edgetech DTS-1) operated by IFM-GEOMAR. The multi-scale analysis includes very precise and detailed sampling and visual observations at the seafloor with water column observations and acoustic records, high-resolution deep tow acoustic images and detailed subbottom profiles, , as well as shipborne bathymetry and backscatter data. Our data allow us to develop a better understanding of the processes governing cold seeps in deep sea fan settings. Well-defined seep environments are presented with, in particular, examples of acoustic water column gas flares linked directly to the originating seafloor seeps (Fig. 3).

\section{Figure 1}

\section{Geological setting}

Faults clearly offer easier seafloor access for seep fluids and are therefore important conduits (Abrams, 1996; Gay et al., 2007; Ligtenberg, 2005; Zitter et al., 2006). Over the Nile Deep Sea Fan, seepage-related structures are not randomly distributed. The tectonic control has been clearly demonstrated for the location of the mud volcanoes (Loncke et al., 2002; Loncke et al., 2004), the shape of the mud volcanoes and the distribution of seeps on the mud volcanoes (Dupré et al., 2007).

The Nile Deep Sea Fan is classically divided into three main sedimentary and morphostructural domains: the Western, the Central and the Eastern Provinces (Bellaiche et al., 2001; Bellaiche et al., 1999; Loncke et al., 2004; Mascle et al., 2001) (Fig. 1). The fluid venting structures are closely related to the fault network, encompassing either deep faults traced to deep-seated basement structures or shallow intra-sedimentary faults induced by salt tectonics or slope instabilities (Loncke et al., 2004; Mascle et al., 2006). In the Central Nile Province, the seafloor is very disturbed by thousands of pockmarks with associated authigenic carbonate crusts (Loncke et al., 2004). The seep activity there is closely associated with sedimentary destabilisation with numerous occurrences of slumps 
and slides that may initiate or promote fluid escape (Bayon et al., 2009). The Eastern Province corresponds to a wide zone of transtensive grabens with NNW-SSE oriented strike-slip faults and is clearly delimited from the Central Province by one of them (Fig. 2). The seafloor morphology and the sedimentary depositional pattern result most likely from a combination of regional transtensional tectonics and the salt tectonic activity (Gaullier et al., 2000), interacting with subsalt inherited basement faults (Loncke et al., 2006).

Figure 2

\section{Previous investigations}

Several seep-related geological structures, identified on ship-borne multibeam swath data (Loncke et al., 2004; Mascle et al., 2006; Sardou and Mascle, 2003), were investigated with the Nautile submersible in 2003 (Bayon et al., 2009; Dupré et al., 2007; Huguen et al., 2009), and later (in 2006) with the Aster ${ }^{x}$ AUV (Autonomous Underwater Vehicle) (Dupré et al., 2008; Foucher et al., 2009). Zones of strong backscatter in multibeam acoustic imagery, commonly interpreted as potential active seepage areas, were mainly observed at the centres of the mud volcanoes. Seismic data have revealed wide and deep seismically transparent columns beneath the surface of the mud volcanoes, attributed to gas-saturated sediments (Abdel et al., 2000; Loncke et al., 2004) forming so-called gas chimneys.

Mud volcanoes on the seafloor are relatively flat structures up to $90 \mathrm{~m}$ high and a few kilometres in diameter (Dupré et al., 2007; Loncke et al., 2004). The seafloor has a variable microtopography with much rougher seafloor composed of ridges and valleys at the eruption sites and a smoother (older) seafloor at larger radial distances unless the surface is broken by a secondary seeping site (e.g. mud dome, authigenic carbonates) (Dupré et al., 2008; Dupré et al., 2007, Gontharet, 2007). Mud volcanoes associated with gas chimneys on the Nile Deep Sea Fan are not as large as other mud volcanoes in terms of volume of mud breccia because their eruptions tend to be more fluid-rich than mud-rich. Gas composition analyses in the water column and within the sediments reveal high concentrations of methane, mainly of thermogenic origin, and higher hydrocarbon gases (Mastalerz et al., 2004; Mastalerz et al., 2007). The centres of the mud volcanoes coincide with elevated temperatures in the sediments (e.g. with more than $40^{\circ} \mathrm{C}$ measured at $10 \mathrm{~m}$ below the seabed in the centre of Amon and Isis mud volcanoes, Dupré et al., 2007; Feseker et al., 2009).

Carbonate precipitation from the oxidized methane-derived carbon (Boetius et al., 2000) led to the formation of small $(\mathrm{mm}$ to $\mathrm{cm}$ ) carbonate concretions within the sediments (Gontharet et al., 2007), very thin ('unconsolidated') to a few metres thick massive deposits, large plates sometimes fractured, and chimney-like build-ups typically less than 1 metre high (Bayon et al., 2009; Dupré et al., 2007). These carbonate structures are found on the southwestern flank of Amon mud volcano (Dupré et al., 2007) and in the western Central Nile Province (1700 and $2100 \mathrm{~m}$ water depths) (Figs. 1 and 2). The dives in this latter region revealed a seafloor disturbed only by carbonate precipitation with no associated mud volcanism. Pockmarks, within which carbonates were partly covered with hemipelagic sediments, and larger carbonate pavements, sometimes fractured and sometimes partly covered with sediments scatter the seafloor there (Bayon et al., 2009). 


\section{Acoustic dataset and methods}

The amplitude of the backscatter signal depends on the frequency characteristics of the originating insonifying signal and of the local seafloor morphology, with a smooth soft seabed backscattering little energy and a stronger signal backscattered from rougher relief. Any internal heterogeneity within the subsurface sediments will increase the level of backscatter from below the seafloor, depending on the relationship between the signal wavelength and the size of the inhomogeneity (Gay et al., 2007; Sager et al., 2003; Volgin and Woodside, 1996; Woodside and Volgin, 1996; Zitter et al., 2005).

\subsection{Water column acoustic records}

The sonar data contains backscatter signals from sources within the water column as well as from the seafloor (Fig. 3). In seep environments, gas bubbles present in the water column may produce acoustic anomalies caused by the impedance contrast between the gas bubbles and the surrounding water (Géli et al., 2008; Merewether et al., 1985; Paull et al., 1995). The detection of gas bubbles depends on their resonant frequency which increases with water depth (De Beukelaer et al., 2003; Greinert and Nützel, 2004). In deep water areas, a tool like the DTS-1 which operates at high frequency $(75 \mathrm{kHz})$ with wide vertical opening angle $\left(70^{\circ}\right)$, and surveying 100 to $200 \mathrm{~m}$ above the seafloor only, is well suited to record the presence of gas in the water column (Klaucke et al., 2005). For instance, at $\sim 900 \mathrm{~m}$ water depths, the EdgeTech DTS-1 sidescan sonar may detect gas bubbles of $0.8 \mathrm{~mm}$ in diameter while conventional systems, hydrographic single beam echosounders (38 kHz) and sediment subbottom profilers $(3.5 \mathrm{kHz})$, will be able to trace only much larger bubbles, > 1.6 and $12 \mathrm{~mm}$, respectively (De Beukelaer et al., 2003). The acoustic anomalies interpreted as the presence of gas bubbles in the water column will be referred to 'gas flares' after Obzhirov et al. (2004), to distinguish them from the nonacoustic 'plumes' of Mastalerz et al. (2007) that are defined as water column volumes with high concentrations of dissolved gas.

Figure 3

\subsection{Backscatter seafloor imagery}

The deep tow sidescan sonar on the DTS-1, operating at a frequency of $75 \mathrm{kHz}$ with a total swath width of $1.5 \mathrm{~km}$, was deployed 100 to $200 \mathrm{~m}$ above the seafloor with a 2.5 knots survey speed during the MIMES expedition (2004). We collected sidescan sonar data along $400 \mathrm{~km}$ track lines corresponding to $\sim 600 \mathrm{~km}^{2}$ (Fig. 1). Two areas were investigated (Fig. 1), one in the eastern Central Nile Province that includes several mud volcanoes (700 to $1400 \mathrm{~m}$ water depths, Fig. 2), and a deeper one (1600 to $1800 \mathrm{~m}$ water depths) in the western Central Nile Province where the seafloor is associated with carbonates. The penetration of the high frequency deep tow signal, and therefore the volume scattering, is less than for conventional shipborne multibeam echosounder (Klaucke et al., 2008; Mitchell, 1993). Processed backscatter maps provide detailed acoustic imagery of the seafloor with a resolution of $1 \mathrm{~m}$, and were obtained using CARAIBES (IFREMER) and PRISM softwares (Le Bas et al., 1995). The processing of the data includes geometric corrections (changes in the ship speed, slant-range correction), 
time varying gain compensation for amplitude loss in the far (horizontal) range and shading correction across track for equalisation of illumination.

The shipborne multibeam data acquired during the previous FANIL expedition (2000) with a Simrad EM300 echosounder, operating at an emission frequency of about $30 \mathrm{kHz}$, provide background seafloor maps with a resolution of $50 \mathrm{~m}$ and $25 \mathrm{~m}$ for the bathymetry and the backscatter imagery, respectively (Sardou and Mascle, 2003) (Fig. 1).

Near bottom surveys performed with the submersible Nautile during the NAUTINIL expedition in 2003 (see explored areas in Fig. 1) provide ground truth for the significance of the geophysical signatures.

\subsection{Chirp data}

The DTS-1 system also comprises a 2-8 kHz Chirp echosounder. It provides vertical resolution of a few tens of centimetres with subseafloor penetration of up to $50 \mathrm{~m}$, and limited to 10 to $20 \mathrm{~m}$ in areas characterized by high backscatter from mud breccia and carbonates. Based on regional knowledge (e.g. Napoli mud volcano area, Robertson et al., 1996) and background values for normal pelagic and hemipelagic sediments (Henry et al., 1990; Lee et al., 2005; Woodside et al., 2003), gassy sediments (Netzeband et al., 2005), carbonates (Netzeband et al., 2005) and stiff mud breccia, an average velocity of $1700 \mathrm{~m} / \mathrm{s}$ has been assumed for estimating the sediment thicknesses and depths derived from the Chirp profiles discussed in this paper. Commonly observed are small faults in the sediments, seafloor irregularities (pockmarks and mounds), sediments containing gas, and hard substrates corresponding to authigenic carbonates. Depending on the sediments and the gas concentrations, gassy sediments may show up as areas of a) acoustic 'wipe outs' (very little signal returned as a result of acoustic attenuation) b) acoustic turbidities (high amplitude scattering obscures any stratification) or c) enhanced reflectors (amplitude of reflections from layers of sediment is strengthened) (Woodside et al., 1998).

\section{Visual observations and geophysical evidence of seep activity}

\subsection{Mud volcanoes associated with gas chimneys}

\subsubsection{Mud volcano DTS-1 seafloor backscatter images}

Seafloor backscatter data allow us to differentiate several classes of generally low backscatter intensity (e.g. Fig. 4b), corresponding to different topographic and/or sedimentary sources. Based on visual observations and long cores (Dupré et al., 2007), these low backscatter intensities correspond to a homogeneous mud breccia (with only small clasts) partly and thinly covered by hemipelagic sediments.

Acoustic shadows. Depending on the incident angle, the acoustic beams, in the presence of topographic highs and depressions, may not reach all parts of the seafloor. Therefore, zones of zero amplitude backscatter (black levels in the figures) may be produced, socalled acoustic shadows (Fig. 4b). Numerous zero amplitude backscatter zones visible on the sonar mosaic maps of the three mud volcanoes are interpreted as acoustic shadows based on the relative bathymetry derived from the subbottom profiles. Some of them clearly correspond to steps in the relief up to $\sim 35$ to $50 \mathrm{~m}$ which form the edges of the mud volcanoes (e.g. NNW and SSE borders of Isis, Fig. 7). The majority of them is associated with the series of concentric ridges and depressions observed along the tracks of the 
Nautile submersible (Dupré et al., 2007). These ridges and depressions are very well imaged by backscatter imagery (Figs. $4 \mathrm{~b}$ and $7 \mathrm{a}$ ) (as well as along the tracks of the towed fish, see e.g. subbottom profiles in Figs. 5 and $7 b$, respectively). These morphological features of a few metres high with wavelengths of $\sim 20$ to $30 \mathrm{~m}$ on average (the full range is 10 to $60 \mathrm{~m}$ ) appear to cover almost all of the surfaces of the mud volcanoes (Figs. 5, 7 and 9). They define an overall concentric architecture around an emission centre but with intersecting and interfingering features.

Figure 4

High backscatter patches. All the high backscatter patches were found by ground truth observation to correspond to gas saturated sediments. The micro-relief (depressions, highs) and the nature of the sediments/rocks both strongly influences the amplitude of the signal. Based on in situ observations and knowledge on the uppermost sedimentary cover, we group the high backscatter zones into three families:

1) Some of the largest high backscatter patches ( $\sim 50$ to $70 \mathrm{~m}$ in diameter) are located at the centre of the most active mud volcanoes, namely Amon and Isis (Dupré et al., 2007) (Figs. 4b and 7a). In contrast, the mud breccia at the surface of Osiris, a less active mud volcano (Dupré et al., 2007), appears to scatter much less energy (Figs. 9a, b and c). There, the main emission centre is not located in the geometric centre of the mud volcano (Figs. 9a, b and c). The large high backscatter patches at the centres of Amon (Fig. 4b) and Isis (Fig. 7a) mud volcanoes are subcircular in shape and appear to be formed by a cluster of smaller high backscatter zones. Chaotic zones of extruded mud breccia contrast there with a smoother and hilly seabed (depressions and mounds of a few $\mathrm{dm}$ to $\sim 1 \mathrm{~m}$ high on average) where the mud breccia is partly covered with dark patches of reduced sediments (Fig. 6) (Dupré et al., 2007). The mud breccia contains millimetric carbonate concretions and the sediments are highly gas saturated. Only a few bigger rock clasts were observed on the seafloor or were recovered within the long cores. Chemosynthetic fauna are not commonly observed in these central zones.

2) A high backscatter band ( $700 \mathrm{~m}$ long and 20 to $80 \mathrm{~m}$ wide, covering $\sim 75000 \mathrm{~m}^{2}$, Fig. 4) characterises the seafloor on the southwestern side of Amon mud volcano. Authigenic carbonates (small chimney-like build-ups and mushroom-shaped constructions, fractured plates) and relatively dense accumulations of dead bivalve shells occur there (Fig. 6) (Dupré et al., 2007; Gontharet et al., 2007). Sediments surrounding the carbonates are gas saturated. This high backscatter band is associated with a NNW-SSE fault system recognized north and south of the mud volcano (Figs. 4a and profile BB' in Fig. 5). Chirp subbottom profiler data image a $10 \mathrm{~m}$ deep and $100 \mathrm{~m}$ wide depression, associated with this fault system (Fig. 5). Variable amplitude of the signal within the band is caused by some clusters of subcircular features with very high backscatter (see north of this band in Fig. 4b).

3) Numerous smaller subcircular high backscatter patches are identified at the surfaces of the mud volcanoes (Figs. $4 \mathrm{~b}$ and $7 \mathrm{a}$ ); most of them at the edges and within the peripheral moats of the mud volcanoes. They are 2 to $5 \mathrm{~m}$ in diameter on average; but, in the case of Isis mud volcano where they are particularly numerous, they may form larger features of about $30 \mathrm{~m}$ in diameter (Fig. 7a). They correspond either to carbonate covered seafloor (fractured plates, massive blocks) associated with numerous bivalves or to small scale dark reduced sediment patches, sometimes associated with a few bushes of tubeworms (Dupré et al., 2007). These areas when sampled reveal a gas saturated environment. 


\subsection{Mud volcano DTS-1 Chirp facies}

\section{Figures 5, 6}

Subbottom profiler data show a chaotic acoustic facies for the mud volcanoes, which is in strong contrast to the acoustic facies of the surrounding well stratified sediments (e.g. Figs. 5, 7b, and 9d), similarly to what is observed on seismic profiles (Abdel et al., 2000; Loncke et al., 2004).

Strong attenuation. The Chirp profiles crossing the mud volcanoes indicate a bumpy seafloor where alternating depressions and elevations have wavelengths of $\sim 20$ to $30 \mathrm{~m}$ on average (the full range is 10 to $60 \mathrm{~m}$ ) in accordance with the values inferred from the backscatter images. The amplitudes of these morphological features are of a few metres (Dupré et al., 2008; Dupré et al., 2007). There are no internal reflections in this facies, which is interpreted to correspond to disturbed and reworked mud breccia sediments composing the mud volcanoes. The signal is strongly attenuated with locally some acoustic blanking in the Chirp sections, so-called wipe outs. These acoustic wipe outs have little lateral extend with a maximum of $20 \mathrm{~m}$ below the active centre of Amon mud volcano (Fig. 5).

Variability among mud volcanoes. The acoustic facies presents significant variations from one mud volcano to another. Whereas Osiris mud volcano exhibits a fairly uniform facies (Fig. 9d), Amon (Fig. 5) and Isis (Fig. 7b) mud volcanoes have both different and distinct acoustic signatures.

At Isis mud volcano, a reflector with higher amplitude is observed a few metres below the seabed where the penetration reached $\sim 15$ to $20 \mathrm{~m}$ on average (Fig. 7b). Visible off the central region of the mud volcano, it roughly follows the seabed without being parallel to it, and is well displayed in particular close to the edges of the mud volcano. It is not clear whether this acoustic feature represents a gas front or a sedimentary interface (e.g. mud breccias cover). Additionally, a few deeper reflection events are visible down to $\sim 40-50 \mathrm{~m}$ below the seabed, just beyond to the edge of the mud volcano in connection with depressions at the seabed (Fig. 7b). The centre and the edges of Isis mud volcano are characterized by significantly higher signal amplitude.

At Amon mud volcano, the strength of the seabed reflection is highly variable (Fig. 5) in comparison to the other mud volcanoes. A strong amplitude facies associated locally with underlying wipe outs a few metres wide are clearly visible in the southwestern depression and in the centre of the mud volcano (Fig. 4b). Both are observed to be active areas with gas saturated sediments. The amplitude of the signal is predominantly enhanced in the southwestern side by the presence of authigenic carbonate deposits (plates, chimney-like build-ups) that outcrop or lie slightly buried below a very thin hemipelagic layer (Fig. 6) (Dupré et al., 2007).

Figures 7, 8 and 9

\subsection{Seeps not associated with mud volcanoes}

Anomalously high backscatter areas are not limited to the surface of the mud volcanoes and many high backscatter patches of various sizes and amplitudes have been identified elsewhere (Figs. 2 and 10 to 13). Chirp profiler data show subhorizontal reflections that are sharply interrupted and replaced, by a very strongly reflective seabed with very low penetration (see e.g. subbottom profiles KK' and LL' in Figs. 11 b and c) just below these 
high backscatter patches. The topography of these areas is rough and made of numerous depressions and highs of a few metres in amplitude (with maximum of $10 \mathrm{~m}$ ). We used ground truth data when available to establish and establish that the high backscatter signatures comes from the observed seafloor authigenic carbonate deposits.

Outside of these seeps, the seabed generally appears as a strong and clear reflector, associated with a medium level of backscatter. The surface of the seabed and the internal reflectors show almost no deformation. The reflectors are subhorizontal. Based on cores, they appear to be well stratified sedimentary layers corresponding to normal hemipelagic sedimentation and undisturbed by wipe outs or faults characteristic of ascending fluids.

Eastern Central Province. In the eastern Central Nile Province, the high backscatter patches are small, and isolated or arranged in clusters (Figs. 2, 10 and 11). The smallest structures, a few metres to a few tens of metres wide, are systematically located within depressions, generally a few metres to occasionally about $20 \mathrm{~m}$ deep (e.g. Fig. 10b). The larger the patches, the more disturbed are the reflections in the underlying and surrounding sediments (Figs. 10 and 11). In some places, the reverberation is high (the length of the acoustic signal associated with the near-seabed high amplitude event reaches $12 \mathrm{~ms}$ in TWT), and any sediments present beneath these inferred carbonate structures are not resolved in the subbottom profiles (Fig. 10b). The largest high backscatter seafloor areas, which are in fact a cluster of small entities, may reach $700 \mathrm{~m}$ in width, and are associated with depressions and topographic highs of a few metres (typically north of Amon mud volcano, Fig. 5).

Many of these high backscatter structures clearly follow lineaments. identified by side scan sonar mosaic analysis (Fig. 2b and 10) and interpreted as superficial seabed expressions of faults. At least some of these are connected to previously identified faults, in particular growth faults induced by salt tectonics (Loncke et al., 2004). We distinguish three major sets of faults based on their orientation and geometry 1) NNW-SSE, 2) NNE-SSW directions (Figs. 2, 10 and 11), and 3) a radial distribution of faults localised around a cluster of high backscatter patches and highly disturbed seafloor (Fig. 8).

\section{Figures 10, 11}

Western Central Province. Although the seafloor in the western investigated Central Province is relatively undisturbed by large faults, and the slope is very gentle and uniform $(1)^{\circ}$, the high-resolution backscatter maps and Chirp profiles reveal a relatively rough seafloor with decimetric microrelief (Figs. 12 and 13). Numerous high backscatter patches are identified there that are almost all subcircular (Figs. 12a and 13a), but they present a much higher variability in their signal amplitude and in their size ( $\mathrm{m}$ to $\mathrm{km}$ in scale) than those found in the eastern Central Nile Province. Three main types have been distinguished:

1) Extremely large patches, reaching 1300 to $1400 \mathrm{~m}$ in width, were identified (Fig. 12a). Irregular in outline, these few patches are characterized by a very high variability in their amplitude.

2) Several subcircular features of 100 to $400 \mathrm{~m}$ average width and with a very high backscatter (exceptionally uniform in amplitude) were identified, contrasting significantly with the low amplitude surroundings (see examples in Fig. 13a).

3) Smaller structures, mostly subcircular, with a diameter of one to a few metres. They generally surround the two types of high backscatter patches described above (Figs. 12a and 13a). With a uniform medium to high amplitude, these high backscatter patches correspond systematically to depressions as much as a few metres deep. In situ observations provide ground truth support for many of the geophysical observations in this area (Bayon et al., 2009). In some places, the centres of these pockmarks contain carbonate crusts and carbonate chimney-like build-ups (Fig. 12c). These structures backscatter a lot of energy causing high amplitude signals. In some others, the carbonate 
depositional constructions within the pockmarks are already partly covered with sediments (Bayon et al., 2009) that backscatter less energy, resulting in the medium amplitude.

These three types of high backscatter patches correspond systematically to 1) a strongly reflective seabed with less reverberation in comparison to the reflective character of the eastern parts of the Central Province, and 2) acoustic wipe outs below, well displayed on Chirp profiles (Figs. 12b and 13b), with however in some places less attenuation allowing some underlying reflections to be distinguished (e.g. along profile NN' in Fig. 13b). Apart from the large high backscatter patches that are more than $100 \mathrm{~m}$ wide, the uppermost sedimentary layers are very well preserved with reflections that can be easily followed down to 30 to $40 \mathrm{~m}$ below seabed. However, these sediments are characterized by numerous narrow (no more than a few metres wide) vertical acoustic wipe outs corresponding systematically at the surface to pockmarks of similar diameter.

\section{Figures 12, 13}

\subsection{Gas detection in the water column}

The acoustic gas flares, described for the first time on the Nile Deep Sea Fan, are systematically associated with a) high backscatter patches on the seafloor vertically below the towed fish and/or just off track, b) strong seabed reflections and c) acoustic wipe outs on sediment echosounder profiles located below the flares. In situ observations showed that the sediments are gas saturated and correspond either to mud breccia in some cases containing millimetric carbonate concretions as well as a few bigger centimetric rock clasts or to authigenic carbonate structures that scatter the seafloor (Bayon et al., 2009; Dupré et al., 2007). A high gas content in the sediments as well as in the water column $(7.5 \mathrm{mmol} / \mathrm{L}$ of wet sediment and up to $1550 \mathrm{nmol} / \mathrm{L}$ within $50 \mathrm{~m}$ above the seafloor, respectively) has been reported for Isis mud volcano (Mastalerz et al., 2007).

A large number of acoustic anomalies ( 60$)$ were recorded (Figs. 2 and 3 ) but even more active seeping sites can be expected in the area as the detection of gas flares in sidescan sonar data is difficult at far range. Seepage activity is widespread on the Nile Deep Sea Fan and acoustic gas 'flares' were detected between 770 and 1700 m water depths:

1) Above the most active mud volcanoes such as the two main emission centres of Amon mud volcano (Figs. 2b, 3c, $4 a$ and 5), which are the geometric centre characterized by recent mud extrusion and the southwestern side, where the seafloor is covered by carbonates. The centre of Isis mud volcano together with its edges and the associated depression ring (Figs. 3b, 7) constitute another example.

2) In the close vicinity of the eastern mud volcanoes (Figs. 2, 4a, 5, 8 and 9).

3) Farther beyond the mud volcanoes (Figs. 2, 10 and 11) as well as in the deeper parts of

the western central delta (Figs. 3a, 12 and 13).

\section{Discussion}

Our high-resolution dataset of 1) acoustic gas 'flares' records, 2) backscatter seafloor imagery and 3) Chirp profiles provides new insights into the seepage activity offshore northern Egypt. Not only has this geophysical data revealed the existence of new seeps but it has brought new knowledge concerning their spatial distribution and temporal 
variability, their level of activity, the formation of the large gas chimneys and other fluid escape structures, and the fluid pathways used, in particular close to the seabed interface.

\subsection{Geophysical detection of seeps}

Wide areas of the Nile Deep Sea Fan seafloor were previously interpreted to be covered with carbonate structures based on high backscatter patches identified from shipborne multibeam data (Loncke et al., 2004). From the new high-resolution sonar dataset it is clear that those parts of the seafloor 1) cover larger surfaces than previously identified or expected (e.g. Figs. 2 and 13) - a lot of them until now below the resolution of available geophysical data -; 2) are disturbed by fluids characterized for most of the investigated structures by sufficient flux to enter the water column. Most of these small scale high backscatter patches are seep-related carbonate structures observed in pockmarks and on low relief mounds. The geophysical dataset reveals that all the mud volcanoes are active with acoustic gas flares recorded above, including mud volcanoes where no in situ data and observations are available (e.g., mud volcanoes named V.1 et V.2 in Loncke et al., 2004, Fig. 8).

The high backscatter in the centre of the mud volcanoes, observed only on the most active mud volcanoes (circular areas of $\sim 50$ to $70 \mathrm{~m}$ in diameter on Amon and Isis, Figs. $4 \mathrm{~b}$ and $7 \mathrm{a}$ ), is principally caused by the rough topography formed by chaotic mud extrusion (Fig. 6), possibly enhanced by the high gas concentrations in the sediments (Klaucke et al., 2006). This interpretation is additionally supported by the fact that the sonar mosaic of the main emission centre on Osiris mud volcano, characterized by a smoother morphology, does not display any significantly high backscatter anomalies (Figs. 9a and c) although sampled sediments exhibit a similar gas saturated mud breccia (de Lange et al., 2006; Dupré et al., 2007; Mastalerz et al., 2004).

The Nile Deep Sea Fan mud volcanoes differ from other Mediterranean mud volcanoes such as the Anaximander ones in many aspects from relief and sedimentary composition to their respective geophysical signatures. The studied Egyptian mud volcanoes generally lack the large clasts and the large volumes of erupted mud found for example on Amsterdam mud volcano (Zitter et al., 2005). In contrast to the geophysical signature of Amon, Isis and Osiris mud volcanoes, stronger backscatter on Amsterdam and Kula mud volcanoes is attributed to a higher density of clasts of all sizes (Volgin and Woodside, 1996) and a rough micro-relief on the copious mud flows which also keeps large parts of the seafloor unstable over longer periods of time.

Carbonate areas are characterized by high to very high backscatter amplitudes due to the strong differences in densities and acoustic velocities between the carbonates and the surrounding mud breccia or hemipelagic sediments (e.g. Figs. 4a, 4b, 10 to 13). The numerous bivalves that partly cover the fractured plates or surround the carbonate chimney-like build-ups, although of small size in the Mediterranean Sea (Olu-Le Roy et al., 2002; Sibuet and Olu, 1998), nevertheless, together with the small relief that forms the carbonate structures (chimney-like build-ups, massif blocks, shields) contribute to enhance the amplitude of the signal (Klaucke et al., 2008; Zitter et al., 2005). The very high backscatter amplitudes together with the acoustic gas flares (e.g. Figs. 3, 4a, 5, 10-13) attest to recent, and most presumably, ongoing seepage by the presence of carbonate crusts outcropping directly at the seabed or slightly buried below a few centimetres sediments. When available in this area, biological and chemical analysis support this view with living chemosynthetic fauna (Bayon et al., 2009; Duperron et al., 2007; Dupré et al., 2007) and anomalously high methane concentrations in the sediments and in the water column (de Lange et al.,2006; Mastalerz et al., 2004; Mastalerz et al., 2007). 
Some of the geophysical parameters can be correlated with a relative level of activity that may indicate a difference in gas fluxes. Although the amplitude of backscatter is not a direct indicator of gas fluxes, high backscatter amplitudes however require sufficient fluxes to precipitate authigenic carbonates or expel mud breccia. The differences observed in echosounder profiles across the three surveyed mud volcanoes clearly reflect differences in seepage intensity. The less active mud volcano (Osiris) exhibits a uniform acoustic facies whereas the most active mud volcanoes (Amon and Isis) are both characterized by internal reflections within the mud breccia facies induced by variations of gas concentrations within the sediments. Some of them may represent gas fronts.

\subsection{Tectonic, structural and sedimentary controls}

Based on sonar data, it appears that distribution of seeps at or near the seabed, in particular regarding the seeps located off the mud volcanoes, is influenced by several factors, possibly in combination: the structural framework and associated fault system, and the orientation of buried channels.

Tectonic control. High backscatter lineations, or a series of high backscatter patches along known (Loncket et al., 2004; Loncke et al., 2006; e.g. Figs. 2 and 9) and newly imaged (e.g. Figs. 2 and 10) fault trends on the seafloor, are interpreted to be the result of carbonates precipitated at seeps along these faults. Carbonates have been seen along some of these lineations both from the submarine as well as the chirp subbottom profilers (e.g. profile BB' in Figs. 5). Some of these faults and fractures outcrop at the seabed and exhibit offsets that are clearly visible on multibeam bathymetric maps (Fig. 2). These faults, for some of which seepage activity was previously suspected (Loncke et al., 2004), are undoubtedly associated with gas emissions as imaged by acoustic gas flares in the water column (Figs. 3), and may be divided into three groups:

(1) The major tectonic corridor that separates the Central Nile Province and the Eastern Nile Province (Loncke et al., 2006; Mascle et al., 2000) (Figs. 1 and 2). The part of this corridor, surveyed by the sidescan sonar and corresponding to the NNE-SSW fault, is the locus of seep activity with a) the first acoustic evidence of gas emissions in the water column (Figs. 2 and 9) and b) numerous high backscatter patches of methane-derived carbonates. The emitted fluids (not sampled) are probably thermogenic in origin considering the tectonic play. According to Loncke et al. (2006), this fault most likely corresponds to an interaction of deeply rooted faults related to the extension of the margin with shallower faults directly connected with salt tectonics.

(2) The numerous listric faults associated with salt tectonics that dissect the upper part of the sedimentary pile (Loncke et al., 2006; Loncke et al., 2004). These normal growth faults do not only control the expulsion of mud at the seabed (Loncke et al., 2004) but are, in the light of the sidescan sonar data, favourable pathways for gases to approach the seabed where carbonates are precipitated (Figs. 2 and 10, example of seepage along N300-310 salt-related faults). Acoustic evidence in the water column (flares) and close to the seafloor with very high backscatter amplitudes from high-frequency sonar system attest to the present-day activity and freshness of the precipitation.

(3) The numerous faults surrounding the active mud volcanoes. Numerous small seeps are identified close to the mud volcanoes (e.g. Figs. 4 and 9). They are not associated with eruptive mud (based on chirp profiles and seafloor backscatter maps) but with carbonate deposits resulting from gas seepage along faults and fractures that develop in the proximity of the mud volcano. Although they generally have little or no bathymetric expression, their acoustic signature makes them clearly visible as high backscatter areas in the sonar mosaics (Fig. 4) and in 3D seismic derived coherency maps, when available 
(Isis and North Alex mud volcanoes, Loncke 2002). Some of them may have occurred synchronously with the mud volcano activity. It is known from 3D seismic data that the numerous concentric faults often observed surrounding mud volcanoes, result from fracturing in the sediments (well expressed e.g. around some mud volcanoes in the Caspian Sea, Stewart and Davies, 2006).

Role of Messinian canyons? In addition to tectonic activity, sedimentation may influence the distribution of seeps. Some places are well known for the correlation between the distribution of seeps relative to buried channels. Pockmarks and channels are strongly linked for instance in the Porcupine Basin where gas accumulations are found along channels, probably related to coarser-grained sediment fill (van Rensbergen et al., 2007). In the Gulf of Guinea, the pockmarks identified on the Zaire Fan line up along the flanks of a buried sandy channel along which fluids migrated laterally (Gay et al., 2003). In the investigated parts of the Central Nile Province and particularly in the eastern region (Figs. 7, 8 and 11), the seeps revealed by the sidescan sonar are not randomly distributed. We have noticed that the associated high backscatter appears to be located above former known Messinian canyons (see in Loncke et al., 2006). For instance, we have observed that the gas emissions detected above the Isis mud volcano (Fig. 7) and the mud volcanoes caldera complex (Fig. 8), coincide with the western limit of a former canyon. Some of these seeps may even follow lineations (e.g. NNW-SSE seep trend exhibited in Fig. 11). We suggest that the orientation of buried channels (i.e. generally perpendicular to the slope contours) plays a role as well in the Nile Deep Sea Fan by controlling the spatial distribution at the seabed of some seeps that are mostly but not exclusively associated with carbonate-related structures. These seeps would be the surface expression of weakness zones in association with fractures and faults located above or in close proximity to Messinian canyons. This view is consistent with the observations of Bentham et al. (2006) that point out a correlation between the location of mud volcanoes and the presence of underlying pre-Messinian structures.

\subsection{Fluid migration}

The escape of fluids through the seabed to the water column appears to occur systematically through narrow vertical pathways, a few metres in diameter on average, regardless of the width of the acoustic wipe outs and whether the seeps are on mud volcanoes or associated with authigenic carbonates.

\subsubsection{Mud volcanoes associated with gas chimneys}

On the most active mud volcanoes, narrow (max of $20 \mathrm{~m}$ diameter) vertical wipe outs are clearly identified just below the surface in the centre of the mud volcanoes (e.g. Fig. 5). With a maximum observed diameter of $20 \mathrm{~m}$, the acoustic wipe outs interpreted to be caused by gas saturated mud breccia most likely form clusters within a wider circle, estimated to be $-120 \mathrm{~m}$ across at the centre of Amon mud volcano (Fig. 4). This view is consistent with the 3D seismic view of other mud volcanic provinces where the width of the feeder channel appears to be much smaller than the zone affected by acoustic blanking or by chaotic reflections (van Rensbergen et al., 1999).

Moreover, the edges of mud volcanoes offer good pathways for seepage (e.g. Isis, Fig. 7). The edges appear to be characterized by carbonate precipitation rather than mud 
extrusion and expulsion, indicating long term seepage. The edges of the mud volcanoes are additional pathways for fluids to escape (see acoustic gas detections in Figs $4 a, 5$ and 7.) possibly because there is a change in the relative sedimentary stress and that the mud volcano forms a sort of 'cap' around which gas migrates upward to escape at the edges.

\subsubsection{Pockmarks and mounds}

Carbonate precipitation with methane derived carbon appears to be a major and constant component in the different seeps on the Nile Deep Sea Fan (Figs 4, 5, 6, 10 to 13). The eastern part of the Central Nile Province, known for mud volcanism, appears to be also more widely disturbed by fluid seepage with most likely the formation of authigenic carbonate structures. The western part of the Central Nile Province, initially inferred to be only poorly active (Bayon et al., 2009, Loncke et al., 2004), appears to have a seafloor scattered with carbonate structures that form in shallow depressions or on small elevated mounds from the edges of which gas may escape.

In a carbonate environment, we know from in situ observations that when the carbonates outcrop at the seabed or the ongoing precipitation occurs in the top sedimentary layers, the gas escapes either through the structures themselves (Mazzini et al., 2008) or at the edges if it is not permeable enough for fluids to migrate through them (Dupré et al., 2007; Naudts et al., 2009; Sager et al., 2003).. This view is supported by our observations that the acoustic gas flares in the water column are often detected at the edges of large high backscatter patches shown from seafloor observation to be carbonate structures (e.g. Figs 4, 12 and 13). U/Th dating of carbonates from the Nile Deep Sea Fan (Bayon et al., 2009) clearly shows evidence for downward growth of the crusts. In addition to the downward thickening of the edifices, we suggest that the seeps are gradually displaced to the edges of the crust as the crust grows, therefore promoting horizontal extension of the crust. If the seep activity is persistent enough, it would lead to the development of large carbonate sheets. This mechanism would explain the formation of the broad carbonate sheets identified in the Western Central Nile Province (1600 to $1800 \mathrm{~m}$ water depths) and extending between 100 and $400 \mathrm{~m}$ in width for the majority of them, to $1400 \mathrm{~m}$ for the largest one.

\subsection{Some insights on mud volcano functioning}

\subsubsection{Present day seabed deformation}

The interfingering pattern on the Nile Deep Sea Fan mud volcanoes of alternating ridges and depressions (e.g. Fig. 4b and profile BB' in Fig. 5) is attributed to the deformation of the mud breccia in response to subvertical stresses localized in the most active emission sites of the mud volcano. The stress distribution in the conduits results in 1) extrusion of mud at the centre of the mud volcano (e.g. see extrusion striations in photo 4 of Fig. 6) and 2) radial deformation off centre. Only a rather limited volume of expelled mud forms the seafloor edifice of the mud volcanoes (maximum volume of about $1.5 \mathrm{~km}^{3}$ for Osiris assuming radius of $2.3 \mathrm{~km}$ and height of $90 \mathrm{~m}$ ) and no mud flows are observed; but the surface deformation with concentric ridges and depressions suggests radial compression consistent with slow central extrusion of mud. We consider the pattern of interfingering shown in Figs 4, 7, and 9 to result from the same energy optimisation resulting from radial compressive stress. 
Similar morphological patterns are observed at the surface of other submarine mud volcanoes in sidescan sonar seafloor imagery maps, e.g. in the Barbados accretionary prism (Atalante mud volcano, Henry et al., 1990), in the Mediterranean Ridge (Moscow mud volcano, Volgin and Woodside, 1996) and in the Anaximander Mountains (Amsterdam mud volcano, Woodside et al., 1998). Le Pichon et al. (1990) interpreted the ridges and depressions as folds caused by shortening of the top surface of Atalante mud volcano. They propose that this seabed morphology is a consequence of the deflation of the central mud lake. On the basis of our multibeam bathymetry data and in situ observations of the Nile Deep Sea Fan mud volcanoes, the central extrusion and radial compression scenario better explains the general morphology of the mud volcanoes and the patterns of surface deformation than the interpretation given for the mud volcanoes seaward of the Barbados accretionary prism i.e. a collapse of these mud structures (Le Pichon et al., 1990).

\subsubsection{Lateral migration of the emission centres through time}

Both backscatter maps and Chirp profiles indicate lateral migration of the main mud eruption sites (e.g. Isis and Osiris, Figs. 7 and 9, respectively). The time difference between the establishment of one centre and another implied by this migration is additionally supported by thermal measurements (Feseker et al., 2009) and gas concentrations (de Lange et al.,2006; Mastalerz et al., 2004; Mastalerz et al., 2007). Our sidescan sonar maps reveal ridges and depressions arranged concentrically around a mud extrusion site, similar to what is exhibited in the more recent high-resolution AUV(Autonomous Underwater Vehicle)-acquired bathymetry data (Amon and Isis mud volcanoes, Dupré et al., 2008). In this view, interfingering of a series of ridges and depressions would be indicative of several successive and distinct mud extrusion pulses. This is clearly recorded at the surface of Osiris mud volcano where two sets of ridges and depressions are clearly visible interfingering in the northern area of the structure. The most recent seabed deformation is identified just to the south of the earlier pattern (Fig. 9b). The associated compressional morphological features correspond to the present-day mud extrusion event, the active centre, identified in the southwestern quarter of the mud volcano (Fig. 9c). The northern set of ridges and depressions are most likely related to an older mud extrusion site, interpreted to be roughly located in the geometrical centre of the mud volcano where no evidence for seeps nor an elevated dome are now observed (Dupré et al., 2007). The distance between these two inferred main mud extrusion sites at Osiris mud volcano is slightly more than $500 \mathrm{~m}$.

The caldera mapped by us (Fig. 8) SW of Isis mud volcano, although not examined by submersible or ROV (Remotely Operated Vehicle), contains several mud volcanoes and seeps. These seeps are considered active on the basis of 1) gas flares detected in the water column at the edge of the caldera (Figs. 8a and b) and 2) backscatter (Fig. 8a) suggesting fresh eruption on another. This indicates that secondary feeder channels for seeps have developed especially around the inner margin of the caldera suggesting that any central conduit beneath the caldera is now blocked at the seafloor. This also supports the observation of higher activity around the margins of mud volcanoes and calderas. 


\section{Conclusions}

Intense seepage activity. The seepage activity in the Central Nile Deep Sea Fan Province is vigorous enough for thermogenic gases to be transported into the water column as bubbles from seeps below. About 60 gas 'flares' were recorded acoustically in the water column. They are systematically correlated with gas blanking in the echosounder profiles and high seabed backscatter.

Widespread seepage activity. The high-resolution sidescan sonar (imaging the sediments, the seafloor and the water column) surveys revealed a great abundance of areas disturbed by ascending fluids, ranging from 700 to 1800 m water depths along the northern Egyptian Margin.

Abundance of seep-related carbonate structures. Fluid seepage on the seafloor is not only concentrated at mud volcanoes but also along faults and at smaller isolated seeps defined by high backscatter (authigenic carbonates) patches and lineations. These latter seeps that scatter the Nile Deep Sea Fan in great number do not extrude mud but are stable enough over longer time periods to promote deposition of authigenic carbonates in the shape of metre-scale chimney-like build-ups or larger plates. Similarly to the large mud volcanoes, the fluid conduits associated with these carbonates, even though numerous and in some places close to each other, are narrow, not exceeding a few metres in diameter on average.

Morpho-acoustic signature of the Nile Deep Sea Fan mud volcanoes. The edges of the mud volcanoes are important pathways for fluids to escape leading most likely to the construction of authigenic carbonate structures. The highest seepage activity recorded at the active centres of the mud volcanoes is well focused within relatively small surface areas. The subcircular seep hotspots coincide with 1) high backscatter centres of $50 \mathrm{~m}$ (Amon mud volcano) to $70 \mathrm{~m}$ (Isis mud volcano) in diameter, 2) clusters of vertical gas-rich conduits up to $20 \mathrm{~m}$ in diameter comprised within wider circles than the seabed imprint of the high backscatter, e.g. $120 \mathrm{~m}$ across at Amon mud volcano, and 3) seabed areas with recently extruded mud breccia blocks of few metres in amplitude. The concentric ridges and depressions of a few metres in amplitude and 20-30 m in wavelength on average are compressional morphological features in response to the radial stress accommodation imposed by the mud extrusion mechanism.

Tectonic and sedimentary control. The tectonic control is evident from seeps clustered along faults and intersections of faults at mud volcanoes. In the eastern part of the Central Nile Province, authigenic carbonate-related seeps located away from the major mud volcanoes, appear to be aligned in the direction of former Messinian canyons.

\section{Acknowledgements}

We would like to express many thanks to the scientists who participated in the MIMES expedition (2004), and the officers and crew of the R/V Pelagia. The DTS-1 sidescan sonar surveys benefited from the great help of Torsten Schott and Dietmar Bürk who were part of our onboard team. For the processing stage, we would like to thank both the scientific teams from GEOMAR in Kiel and IFREMER Research Centre in Brest, especially Reimer Wilhelm Weinrebe, Eliane Le Drezen and Jean-Marie Augustin for their guidance and advice. MIMES was a part of MEDIFLUX, a cooperative Dutch-FrenchGerman programme, endorsed and promoted by the European Science Foundation within its EUROMARGINS initiative (contract No. ERAS-CT-2003-980409 of the European Commission, DG Research, FP6). The Netherlands Organisation for Scientific Research 
(NWO) is thanked for the Dutch financial support within MEDIFLUX through NWO/ALW project 855.01.031.

\section{References}

Aal, A.A., El Barkooky, A., Gerrits, M., Meyer, H., Schwander, M., Zaki, H., 2000. Tectonic evolution of the eastern Mediterranean Basin and its significance for hydrocarbon prospectivity in the ultradeepwater of the Nile Delta. The Leading Edge, 19: 1086-1102.

Abrams, M.A., 1996. Distribution of subsurface hydrocarbon seepage in near-surface marine sediments. AAPG Memoir, 66: 1-14.

Alexandri, M., 2007. Classification and interpretation of seabed geology from analysis of sonar data. Unpublished PhD thesis, University of Birmingham, United Kingdom, 500 pp.

Bayon, G., Henderson, G.M. and Bohn, M., 2009. U-Th stratigraphy of a cold seep carbonate crust. Chemical Geology, 260: 47-56.

Bayon, G., Loncke, L., Dupré, S., Caprais, J.C., Ducassou, E., Duperron, S., Etoubleau, J., Foucher, J.P., Fouquet, Y., Gontharet, S., Henderson, G.M., Huguen, C., Klaucke, I., Mascle, J., Migeon, S., Olu-Le Roy, K., Ondréas, H., Pierre, C., Sibuet, M., Stadnitskaia, A., Woodside, J., Marine Geology. Multi-disciplinary investigation of fluid seepage on an unstable margin: The case of the Central Nile deep sea fan. Marine Geology,, 261: 92104.

Bellaiche, G., Loncke, L., Gaullier, V., Mascle, J., Courp, T., Moreau, A., Radan, S., Sardou, O., 2001. Le cône sous-marin du Nil et son réseau de chenaux profonds; nouveaux résultats (campagne Fanil). Comptes Rendus de l'Académie des Sciences, Série II. Sciences de la Terre et des Planètes, 333: 399-404.

Bellaiche, G., Zitter, T., Droz, L., Gaullier, V., Mart, Y., Mascle, J., Prismed Equipe Scientifique France, 1999. Le Cône sous-marin profond du Nil; principaux résultats de la campagne PRISMED II du N.O. I'Atalante. Comptes Rendus de l'Académie des Sciences, Série II. Sciences de la Terre et des Planètes, 329: 727-733.

Bentham, P., Pasley, M., Birt, C., 2006. The Style and Timing of Mud Volcanism in the Offshore Nile Delta, Egypt. Paris 2005 AAPG International Conference and Exhibition; abstracts.

Boetius, A., Ravenschlag, K., Schubert, C.J., Rickert, D., Widdel, F., Gieseke, A., Amann, R., Jorgensen, B.B., Witte, U., Pfannkuche, O., 2000. A marine microbial consortium apparently mediating anaerobic oxidation of methane. Nature, 407: 623-626.

De Beukelaer, S.M., MacDonald, I.R., Guinnasso, N.L., Murray, J.A., 2003. Distinct sidescan sonar, RADARSAT SAR, and acoustic profiler signatures of gas and oil seeps on the Gulf of Mexico slope. Geo-Marine Letters, 23: 177-186.

de Lange, G., Mastalerz, V., Dählmann, A., Haese, R., Mascle, J., Woodside, J.M., Foucher, J.-P., Lykousis, V., ,Michard, A., 2006. Geochemical composition and origin for fluid and gas fluxes at Eastern Mediterranean mud volcanoes. CIESM Workshop Monograph. Fluids seepages / mud volcanism in the Mediterranean and adjacent domains, 29: 103-110.

Dimitrov, L., Woodside, J., 2003. Deep sea pockmark environments in the eastern Mediterranean. Marine Geology, 195: 263-276.

Dimitrov, L.I., 2002. Mud volcanoes--the most important pathway for degassing deeply buried sediments. Earth-Science Reviews, 59: 49-76.

Dolson, J.C., Shann, M.V., Matbouly, S., Harwood, C., Rashed, R., Hammouda, H., 2001. The petroleum potential of Egypt. AAPG Memoir, 74: 453-482.

Duperron, S., Fiala-Médioni, A., Caprais, J.-C., Olu-Le Roy, K., Sibuet, M., 2007. Evidence for chemoautotrophic symbiosis in a Mediterranean cold seep clam (Bivalvia: Lucinidae): 
comparative sequence analysis of bacterial 16S rRNA, APS reductase and RubisCO genes. FEMS Microbiology Ecology, 59: 64-70.

Dupré, S., Buffet, G., Mascle, J., Foucher, J.-P., Gauger, S., Boetius, A., Marfia, C., the AsterX AUV Team, the Quest ROV Team, the BIONIL Scientific Party, 2008. Highresolution mapping of large gas emitting mud volcanoes on the Egyptian continental margin (Nile Deep Sea Fan) by AUV surveys. Marine Geophysical Researches: 29: 275290.

Dupré, S., Woodside, J., Foucher, J.-P., de Lange, G., Mascle, J., Boetius, A., Mastalerz, V., Stadnitskaia, A., Ondréas, H., Huguen, C., Harmegnies, F., Gontharet, S., Loncke, L., Deville, E., Niemann, H., Omoregie, E., Olu-Le Roy, K., Fiala-Medioni, A., Dählmann, A., Caprais, J.-C., Prinzhofer, A., Sibuet, M., Pierre, C., Sinninghe Damsté, J., NAUTINIL scientific Party, 2007. Seafloor geological studies above active gas chimneys off Egypt (Central Nile Deep Sea Fan). Deep Sea Research Part I: Oceanographic Research Papers, 54: 1146-1172.

Feseker, T., Dählmann, A., Foucher, J.P. and Harmegnies, F., 2009. In-situ sediment temperature measurements and geochemical porewater data suggest highly dynamic fluid flow at Isis mud volcano, eastern Mediterranean Sea. Marine Geology, 261: 128-137.

Foucher, J.-P., Westbrook, G.K., Boetius, A., Ceramicola, S., Dupré, S., Mascle, J., Mienert, J., Pfannkuche, O., Pierre, C., Praeg, D., 2009. Structure and drivers of hydrocarbon seep ecosystems in the European seas: An overview from HERMES results. Oceanography, 22: 92-109.

Gaullier, V., Mart, Y., Bellaiche, G., Mascle, J., Vendeville, B.C., Zitter, T., Benkhelil, J., Buffet, G., Droz, L., Ergun, M., Huguen, C., Kopf, A., Levy, R., Limnov, A., Shaked, Y., Volkonskaia, A., Woodside, J.M., Prismed II Second Leg Scientific Party France, 2000. Salt tectonics in and around the Nile deep-sea fan; insights from the PRISMED II cruise. Geological Society Special Publications, 174: 111-129.

Gay, A., Lopez, M., Cochonat, P., Sultan, N., Cauquil, E., Brigaud, F., 2003. Sinuous pockmark belt as indicator of a shallow buried turbiditic channel on the lower slope of the Congo Basin, West African margin. Geological Society Special Publications, Subsurface sediment mobilization., 216: 173-189.

Gay, A., Lopez, M., Berndt, C., Séranne, M., 2007. Geological controls on focused fluid flow associated with seafloor seeps in the Lower Congo Basin. Marine Geology, 244: 6892.

Géli, L., Henry, P., Zitter, T., Dupré, S., Tryon, M., Çagatay, M.N., Mercier de Lépinay, B., Le Pichon, X., Sengör, A.M.C., Görür, N., Natalin, B., Uçarkus, G., Özeren, S., Volker, D., Gasperini, L., Bourlange, S., 2008. Gas emissions and active tectonics within the submerged section of the North Anatolian Fault zone in the Sea of Marmara. Earth and Planetary Science Letters, 274: 34-39.

Gontharet, S., Pierre, C., Blanc-Valleron, M.M., Rouchy, J.M., Fouquet, Y., Bayon, G., Foucher, J.P., Woodside, J., Mascle, J., 2007. Nature and origin of diagenetic carbonate crusts and concretions from mud volcanoes and pockmarks of the Nile deep-sea fan (eastern Mediterranean Sea). Deep Sea Research Part II: Topical Studies in Oceanography, 54: 1292-1311.

Greinert, J., Nützel, B., 2004. Hydroacoustic experiments to establish a method for the determination of methane bubble fluxes at cold seeps. Geo-Marine Letters, 24: 75-85.

Henry, P., Le Pichon, X., Lallemant, S., Foucher, J.P., Westbrook, G.K., Hobart, M.A., 1990. Mud volcano field seaward of the Barbados accretionary complex; a deep-towed scan sonar. Journal of Geophysical Research, 95: 8917-8929.

Hovland, M., Judd, A.G., 1988. Seabed Pockmarks and Seepages. Impact on Geology, Biology and the Marine Environment. Graham \& Trotman, London, 293 pp.

Huguen, C., Foucher, J.P., Mascle, J., Ondréas, H., Thouement, M., Gontharet, S., Stadnitskaia, A., Pierre, C., Bayon, G., Loncke, L., Boetius, A., Bouloubassi, I., de Lange, G., Caprais, J.C., Fouquet, Y., Woodside, J., Dupré, S., 2009. Menes caldera, a highly 
active site of brine seepage in the eastern Mediterranean sea: "In situ" observations from the Nautinil expedition (2003). Marine Geology, 261:138-152.

Huguen, C., Mascle, J., Chaumillon, E., Kopf, A., Woodside, J., Zitter, T., 2004. Structural setting and tectonic control of mud volcanoes from the Central Mediterranean Ridge (Eastern Mediterranean). Marine Geology, 209: 245-263.

Judd, A.G., Hovland, M., 2007. Seabed Fluid Flow. The Impact on Geology, Biology and the Marine Environment. Cambridge University Press, 293 pp.

King, L.H., MacLean, B., 1970. Pockmarks on the Scotian Shelf. Geological Society of America Bulletin, 81: 3141-3148.

Klaucke, I., Masson, D.G., Petersen, C., Weinrebe, J.W., Ranero, C.R., 2008. Multifrequency geoacoustic imaging of fluid escape structures offshore Costa Rica: Implications for the quantification of seep processes. Geochemistry Geophysics Geosystems, 9, Q04010, doi:10.1029/2007GC001708.

Klaucke, I., Sahling, H., Buerk, D., Weinrebe, W., Bohrmann, G., 2005. Mapping deepwater gas emissions with sidescan sonar. Eos, Transactions, American Geophysical Union, 86: 341, 346.

Klaucke, I., Sahling, H., Weinrebe, W., Blinova, V., Burk, D., Lursmanashvili, N., Bohrmann, G., 2006. Acoustic investigation of cold seeps offshore Georgia, eastern Black Sea. Marine Geology, 231: 51-67.

.Le Bas, T.P., Mason, D.C., Millard, N.C., 1995. TOBI image processing-the state of the art. IEEE Journal of Oceanic Engineering, 20: 85-93.

Le Pichon, X., Foucher, J.P., Boulegue, J., Henry, P., Lallemant, S., Benedetti, M., Avedik, F., Mariotti, A., 1990. Mud volcano field seaward of the Barbados accretionary complex; a submersible survey. Journal of Geophysical Research, 95: 8931-8943.

Lee, T.-G., Hein, J.R., Lee, K., Moon, J.-W., Ko, Y.-T., 2005. Sub-seafloor acoustic characterization of seamounts near the Ogasawara Fracture Zone in the western Pacific using chirp (3-7 kHz) subbottom profiles. Deep Sea Research Part I: Oceanographic Research Papers, 52: 1932-1956.

Ligtenberg, J.H., 2005. Detection of fluid migration pathways in seismic data: implications for fault seal analysis. Basin Research, 17: 141-153.

Loncke, L., 2002. Le delta profond du Nil: structure et évolution depuis le Messinien, Thèse de doctorat de I'Université P. et M. Curie (Paris 6), 180 pp.

Loncke, L., Gaullier, V., Bellaiche, G., Mascle, J., 2002. Recent depositional patterns of the Nile deep-sea fan from echo-character mapping. AAPG Bulletin, 86: 1165-1186.

Loncke, L., Gaullier, V., Mascle, J., Vendeville, B., Camera, L., 2006. The Nile deep-sea fan: An example of interacting sedimentation, salt tectonics, and inherited subsalt paleotopographic features. Marine and Petroleum Geology, 23: 297-315.

Loncke, L., Mascle, J., Fanil Scientific Parties, 2004. Mud volcanoes, gas chimneys, pockmarks and mounds in the Nile deep-sea fan (eastern Mediterranean); geophysical evidences. Marine and Petroleum Geology, 21: 669-689.

Lykousis, V., Alexandri, S., Woodside, J., de Lange, G., Dählmann, A., Perissoratis, C., Heeschen, K., Ioakim, C., Sakellariou, D., Nomikou, P., Rousakis, G., Casas, D., Ballas, D., Ercilla, G., 2009. Mud volcanoes and gas hydrates in the Anaximander mountains (Eastern Mediterranean Sea). Marine and Petroleum Geology,26: 854-872.

Mascle, J., Benkhelil, J., Bellaiche, G., Zitter, T., Woodside, J., Loncke, L., Prismed II Cruise Shipboard Scientific Party France, 2000. Marine geologic evidence for a LevantineSinai Plate; a new piece of the Mediterranean puzzle. Geology, 28: 779-782.

Mascle, J., Sardou, O., Loncke, L., Migeon, S., Caméra, L., Gaullier, V., 2006. Morphostructure of the Egyptian Continental Margin: Insights from Swath Bathymetry Surveys. Marine Geophysical Researches, 27: 49-59.

Mascle, J., Zitter, T., Bellaiche, G., Droz, L., Gaullier, V., Loncke, L., Prismed Scientific Party France, 2001. The Nile deep sea fan; preliminary results from a swath bathymetry survey. Marine and Petroleum Geology, 18: 471-477. 
Mastalerz, V., Dählmann, A., de Lange, G.J., the NAUTINIL and ANAXIMANDER Scientific Parties, 2004. Methane venting at mud volcanoes from the East Mediterranean Ridge and the Nile Deep-Sea Fan. Geophysical Research Abstracts: 6: 422.

Mastalerz, V., de Lange, G.J., Dahlmann, A., Feseker, T., 2007. Active venting at the Isis mud volcano, offshore Egypt: Origin and migration of hydrocarbons. Chemical Geology, 246: 87-106.

Mazzini, A., Ivanov, M.K., Nermoen, A., Bahr, A., Bohrmann, G., Svensen, H., Planke, S., 2008. Complex plumbing systems in the near subsurface: Geometries of authigenic carbonates from Dolgovskoy Mound (Black Sea) constrained by analogue experiments. Marine and Petroleum Geology, 25: 457-472.

Merewether, R., Olsson, M.S., Lonsdale, P., 1985. Acoustically detected hydrocarbon plumes rising from 2-km depths in Guaymas Basin, Gulf of California. Journal of Geophysical Research, 90: 3075-3085.

Mitchell, N.C., 1993. A Model for Attenuation of Backscatter due to Sediment Accumulations and Its Application to Determine Sediment Thicknesses With GLORIA Sidescan Sonar. Journal of Geophysical Research, 98: 22,477-22,493.

Naudts, L., De Batist, M., Greinert, J., Artemov, Y., 2009, Geo- and hydro-acoustic manifestations of shallow gas and gas seeps in the Dnepr paleodelta, northwestern Black Sea. The Leading Edge, 28:1030-1040.

Netzeband, G.L., Hübscher, C.P., Gajewski, D., Grobys, J.W.G., Bialas, J., 2005. Seismic velocities from the Yaquina forearc basin off Peru: evidence for free gas within the gas hydrate stability zone. International Journal of Earth Sciences, 94: 420-432.

Obzhirov, A., Shakirov, R., Salyuk, A., Suess, E., Biebow, N.S.A., 2004. Relations between methane venting, geological structure and seismo-tectonics in the Okhotsk Sea. Geo-Marine Letters, 24: 135-139.

Olu-Le Roy, K., Sibuet, M., Fiala-Médioni, A., Gofas, S., Salas, C., Mariotti, A., Foucher, J.-P., Woodside, J., 2002. Cold seep communities in the deep eastern Mediterranean Sea: composition, symbiosis and spatial distribution on mud volcanoes. Deep Sea Research Part I: Oceanographic Research Papers, 51: 1915-1936.

Ostrovsky, 2003. Methane bubbles in Lake Kinneret: Quantification and temporal and spatial heterogeneity. Limnology and Oceanography, 48: 1030-1036.

Paull, C.K., Ussler, W., III, Borowski, W.S., Spiess, F.N., 1995. Methane-rich plumes on the Carolina continental rise; associations with gas hydrates. Geology, 23: 89-92.

Pilcher, R., Argent, J., 2007. Mega-pockmarks and linear pockmark trains on the West African continental margin. Marine Geology, 244: 15-32.

Robertson, A.H.F., Emeis, K.C., Richter, C., Blanc, V.M.M., Bouloubassi, I., Brumsack, H.J., Cramp, A., de Lange, G.J., Di Stefano, E., Flecker, R., Frankel, E., Howell, M.W., Janecek, T.R., Jurado, R.M.J., Kemp, A.E.S., Koizumi, I., Kopf, A., Major, C.O., Mart, Y., Pribnow, D.F.C., Rabaute, A., Roberts, A.P., Rullkoetter, J.H., Sakamoto, T., Spezzaferri, S., Staerker, T.S., Stoner, J.S., Whiting, B.M., Woodside, J.M., Ocean Drilling Program Leg 160 Shipboard Scientific Party, 1996. Mud volcanism on the Mediterranean Ridge. In: Proceedings of the Ocean Drilling Program, initial reports; Mediterranean I; covering Leg 160 of the cruises of the drilling vessel JOIDES Resolution, Las Palmas, Gran Canaria, to Naples, Italy, Sites 963-973, 7 March-3 May, 1995. Proceedings of the Ocean Drilling Program, Part A: Initial Reports, 160: 521-526.

Sager, W.W., MacDonald, I.R., Hou, R., 2003. Geophysical signatures of mud mounds at hydrocarbon seeps on the Louisiana continental slope, northern Gulf of Mexico. Marine Geology, 198: 97-132.

Sardou, O., Mascle, J., 2003. Cartography by multibeam echo-sounder of the Nile deepsea Fan and surrounding areas (2 sheets). Special publication CIESM, Monaco.

Sibuet, M., Olu, K., 1998. Biogeography, biodiversity and fluid dependence of deep-sea cold-seep communities at active and passive margins. Deep Sea Research Part II: Topical Studies in Oceanography, 45: 517-567. 
Stewart, S.A., Davies, R.J., 2006. Structure and emplacement of mud volcano systems in the South Caspian Basin. AAPG Bulletin, 90: 771-786.

van Rensbergen, P., Morley, C.K., Ang, D.W., Hoan, T.Q., Lam, N.T., 1999. Structural evolution of shale diapirs from reactive rise to mud volcanism; 3D seismic data from the Baram Delta, offshore Brunei Darussalam. Journal of the Geological Society of London, 156: 633-650.

van Rensbergen, P., Rabaute, A., Colpaert, A., Ghislain, T.S., Mathijs, M., Bruggeman, A., 2007. Fluid migration and fluid seepage in the Connemara Field, Porcupine Basin interpreted from industrial 3D seismic and well data combined with high-resolution site survey data. International Journal of Earth Sciences, 96: 185-197.

Volgin, A.V., Woodside, J.M., 1996. Sidescan sonar images of mud volcanoes from the Mediterranean Ridge: possible causes of variations in backscatter intensity. Marine Geology, 132: 39-53.

Woodside, J.M., Ivanov, M.K., Limonov, A.F., 1998. Shallow gas and gas hydrates in the Anaximander Mountains region, eastern Mediterranean Sea. Geological Society Special Publications, 137: 177-193.

Woodside, J.M., Modin, D.I., Ivanov, M.K., 2003. An enigmatic strong reflector on subbottom profiler records from the Black Sea-the top of shallow gas hydrate deposits. Geo-Marine Letters, 23: 269-277.

Woodside, J.M., Volgin, A.V., 1996. Brine pools associated with Mediterranean Ridge mud diapirs: an interpretation of echo-free patches in deep tow sidescan sonar data. Marine Geology, 132: 55-61.

Zitter, T.A.C., Huguen, C., ten Veen, J., Woodside, J.M., 2006. Tectonic control on mud volcanoes and fluid seeps in the Anaximander Mountains, eastern Mediterranean Sea. 409: 615-631.

Zitter, T.A.C., Huguen, C., Woodside, J.M., 2005. Geology of mud volcanoes in the eastern Mediterranean from combined sidescan sonar and submersible surveys. Deep Sea Research Part I: Oceanographic Research Papers, 52: 457-475. 


\section{Figures}

Figure 1

Shaded morphological bathymetry map of the Nile Deep Sea Fan after Sardou and Mascle (2003). During the MIMES expedition in 2004, two main areas were investigated, 1) the eastern part of the Central Province (700 to $1400 \mathrm{~m}$ of water depths) that comprises three large mud volcanoes located above gas chimneys and 2) the western and deeper part of the Central Province (1600 to $1800 \mathrm{~m}$ of water depths) where the seafloor is characterized by numerous authigenic carbonate seep-related structures. MV stands for Mud Volcano.

Figure 2

a) Shaded bathymetry (Sardou and Mascle, 2003) and b) morpho-structural maps of the eastern Central Province investigated during the MIMES expedition, 2004. Shown are the distribution of the 60 detected acoustic gas flares and the (superficial) outcropping faults and fluid-related-disturbed seafloor areas, both determined by sidescan sonar processed mosaic inspection.

Figure 3

Acoustic anomalies detected in the water column in the sidescan sonar record (unprocessed backscatter imagery) for the different investigated fluid seepage environments of the Nile Deep Sea Fan during the MIMES expedition (2004) (a, b and c), and corresponding seafloor photographs taken onboard the Nautile submersible (NAUTINIL, 2003) (d, e, and f, respectively). a) Pockmarks and metre-scale authigenic carbonate chimney-like build-ups located in the western part of the Central Province (1687 $\mathrm{m}$ water depths). b) Main emission site in the central and slightly elevated dome of Isis mud volcano located on the eastern side of the former Messinian shelf $(990 \mathrm{~m}$ water depths). c) Carbonate crust structures aligned along a NNW-SSE fault that crosses the southwestern side of Amon mud volcano (1146 m water depths). For locations of the sites and gas flares, see processed backscatter seafloor images in Figs. 12a, 7a and 4a, respectively.

Figure 4

High-resolution geophysical signature of Amon mud volcano (wd 1100m) and its surroundings from $75 \mathrm{kHz}$ sidescan sonar data acquired during the MIMES expedition in 2004 in the eastern Central Nile Province. See location in Figs. 1 and 2. a) Processed seafloor backscatter imagery. Red dots refer to strong and large water column acoustic anomalies observed in the DTS-1 sidescan sonar data (Fig. 3), most of them crosscorrelated with the red arrows along the Chirp profiles (Fig. 5). $20 \mathrm{~m}$ isobaths are from Sardou and Mascle (2003). b) Zoom from Fig. 4a. The amplitude of the backscatter signal results from the microrelief and the nature of the penetrated sediments. Two major types of acoustic shadows (low amplitude backscatter zones) are identified at the surface of Amon mud volcano. The edge of the structure exhibits steps of up to 35-50 m (type I). The top surface of the mud volcano is deformed by an alternance of ridges/bumps and depressions of a few meters high (type II). These morphological features correspond to deformation of mud breccia that has been previously extruded and later on compressed by radial stresses from the emission centre. The strongest backscatter amplitudes correspond to active emission sites where the sediments are gas saturated and associated with mud breccia extrusion in the centre of the mud volcano (type III, see pictures 1 to 4 in Fig. 6) and authigenic carbonate precipitation on the southwestern flank (type IV, see pictures 5 and 6 in Fig. 6). Sonar mosaics revealed zones of destabilized sediments that are gravity induced debris flows of mud breccia (type $\mathrm{V}$ and $\mathrm{VI}$ in the southern and eastern border of Amon mud volcano, respectively). 
Figure 5.

Deep tow subbottom 2-8 kHz Chirp profiles north of Amon mud volcano (profile $A A^{\prime}$ ) and across the Amon mud volcano (profile BB', note that the point B' is aligned with BB1 but is located off the frame of Fig. 4a, east-northeast of B1). V. E. stands for vertical exaggeration.

\section{Figure 6}

Near bottom pictures taken from the submersible Nautile (NAUTINIL expedition, 2003) in the centre of Amon mud volcano (1-4) and on the southwestern flank covered by carbonate structures (chimney-like build-ups, fractured plates) (5-6).

\section{Figure 7}

High-resolution geophysical signature of Isis mud volcano (wd 1100m) from $75 \mathrm{kHz}$ sidescan sonar data acquired during the MIMES expedition in 2004 in the eastern Central Nile Province (Figs. 1 and 2). a) Processed seafloor backscatter imagery. Coloured dots refer to water column acoustic anomalies observed in the DTS-1 sidescan sonar data, cross-correlated with the coloured arrows along the Chirp profiles below (see for details the legend in Fig. 5). See caption of Fig. 4 for significance of labelling I to V. b) Deep tow subbottom 2-8 kHz Chirp profiles across the Isis mud volcano (profiles CC', DD' and EE'). V. E. stands for vertical exaggeration.

\section{Figure 8}

High-resolution geophysical signature of a mud volcano caldera complex (wd 700 to $1100 \mathrm{~m}$ ) from $75 \mathrm{kHz}$ sidescan sonar data acquired during the MIMES expedition in 2004 in the eastern Central Nile Province. This caldera is located $\sim 9 \mathrm{~km}$ south of Isis mud volcano (Fig. 2). a) Processed seafloor backscatter imagery. The red and orange dots refer to water column acoustic anomalies observed in the DTS-1 sidescan sonar data, some of them cross-correlated with the similarly coloured arrows along the Chirp profile below (see for details the legend in Fig. 5). b) Deep tow subbottom 2-8 kHz Chirp profile across the eastern border of the caldera complex (profile FF'). V. E. stands for vertical exaggeration. c) Shipborne bathymetry map (Sardou and Mascle, 2003) where are shown the track lines of the sonar together with the acoustic anomalies detected in the water column and displayed as small dots.

Figure 9

High-resolution geophysical signature of Osiris mud volcano and its close surroundings (wd 760 to $960 \mathrm{~m}$ ) from $75 \mathrm{kHz}$ sidescan sonar data acquired during the MIMES expedition in 2004 in the eastern Central Nile Province. See location in Figs. 1 and 2. a) Processed seafloor backscatter imagery. $20 \mathrm{~m}$ isobaths are from Sardou and Mascle (2003). The coloured dots refer to water column acoustic anomalies observed in the DTS1 sidescan sonar data, most of them cross-correlated with the similarly coloured arrows along the Chirp profiles below (see for details the legend in Fig. 5). b) and c) Zooms of the a) mosaic focus respectively on 1) on the northern part of Osiris where the seafloor exhibits interfingering features interpreted to be caused by several distinct and successive mud extrusion events associated with different emission centres; and 2) the most recent and main emission centre of the mud volcano covered with gas saturated mud breccia and not located at the geometric centre of the mud volcano structure but in the southwestern quadrant of it. d) Deep tow subbottom 2-8 kHz Chirp profiles across Osiris mud volcano (for profile GG', note that the points G' and G1 are aligned with G2G' but are located off the frame of Fig. 9a, west-southwest of G2) and south of the mud volcano (profile HH'). V. E. stands for vertical exaggeration. 
Figure 10

High-resolution geophysical signature of seeps from $75 \mathrm{kHz}$ sidescan sonar data acquired during the MIMES expedition in 2004 in the eastern Central Nile Province (wd 1100 to $1200 \mathrm{~m}$ ). These seeps are located $\sim 3 \mathrm{~km}$ south of the active Amon mud volcano (Figs. 1 and 2). a) Processed seafloor backscatter imagery. $10 \mathrm{~m}$ isobaths are from Sardou and Mascle (2003). Dots refer to water column acoustic anomalies observed in the DTS-1 sidescan sonar data, cross-correlated with the arrows along the Chirp profile below (see for details the legend in Fig. 5). b) Deep tow subbottom 2-8 kHz Chirp profile across the fault system (profile II', note that the points I and I' are aligned with III2 but are located out of the frame of Fig. 10a, west-southwest and east-northeast of I1, respectively). V. E. stands for vertical exaggeration. These seeps are clearly following lineations that correspond to NW-SE faults (Fig. 2).

Figure 11

High-resolution geophysical signature of seeps from $75 \mathrm{kHz}$ sidescan sonar data acquired during the MIMES expedition in 2004 in the eastern Central Nile Province. These seeps are located off the active mud volcanoes, and are aligned with fault NW-SE running faults that dissect the margin (Figs. 1 and 2). a) and b) WSW-ENE oriented deep tow subbottom 2-8 kHz Chirp profiles (profiles JJ' and KK' located out of frame to the north of L1L2 profile).. c) Deep tow subbottom 2-8 kHz Chirp profile (profiles LL', note that the points L and L' are aligned with L1L2 but are located off the frame of Fig. 11d, west-southwest and east-northeast of $L 1$, respectively. Arrows refer to water column acoustic anomalies observed in the DTS-1 sidescan sonar data, some of them cross-correlated with the dots on the sonar mosaic below (see for details the legend in Fig. 5). V. E. stands for vertical exaggeration. d) corresponding processed seafloor backscatter imagery. $20 \mathrm{~m}$ isobaths are from Sardou and Mascle (2003). The backscatter signature of the seeps along the profile $\mathrm{JJ}$ ' and KK' are similar to the one exposed in Fig. 11d.

Figure 12

High-resolution geophysical signature of carbonate related structures located in the Western Central Nile Province (wd 1680 to $1700 \mathrm{~m}$ ) from $75 \mathrm{kHz}$ sidescan sonar data acquired during the MIMES expedition in 2004. See location in Fig. 1. a) Processed seafloor backscatter imagery. Dots refer to water column acoustic anomalies observed in the DTS-1 sidescan sonar data, cross-correlated with the arrows along the Chirp profile below (see for details the legend in Fig. 5). b) Deep tow subbottom 2-8 kHz Chirp profile. c) Near bottom pictures taken from the submersible Nautile (NAUTINIL expedition, 2003) in the southern border of the western high backscatter patches: metre-scale coalescent pockmarks and carbonate chimney-like build-ups $(1,2)$, and fractured carbonate plates partly covered with a thin hemipelagic sediments (3).

Figure 13

High-resolution geophysical signature of carbonate related structures located in the Western Central Nile Province (wd 1680 to $1720 \mathrm{~m}$ ) from $75 \mathrm{kHz}$ sidescan sonar data acquired during the MIMES expedition in 2004. See location in Fig. 1. a) Processed seafloor backscatter imagery. Dots refer to water column acoustic anomalies observed in the DTS-1 sidescan sonar data, cross-correlated with the arrows along the Chirp profile below (see for details the legend in Fig. 4). b) Deep tow subbottom 2-8 kHz Chirp profile. 


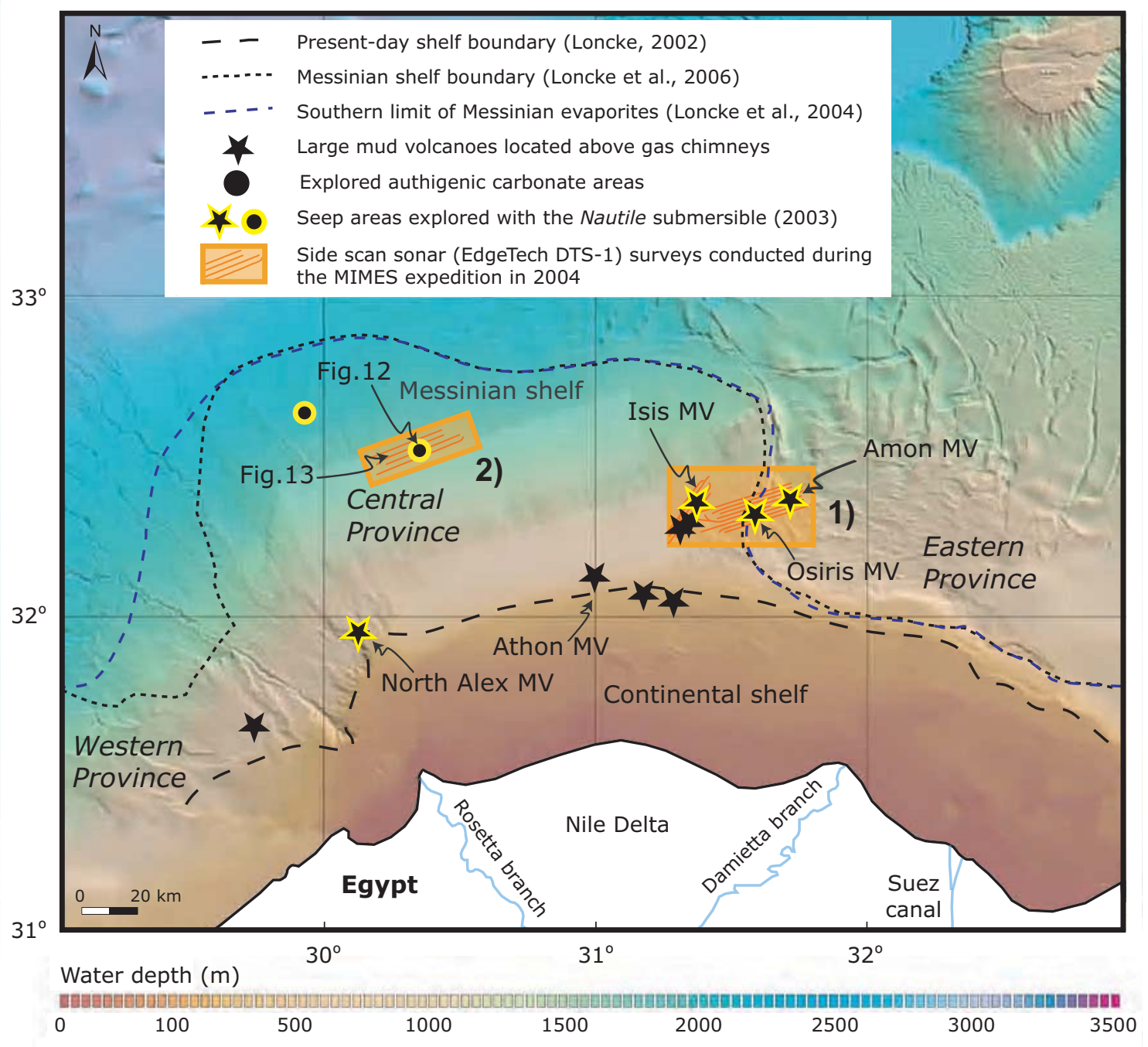




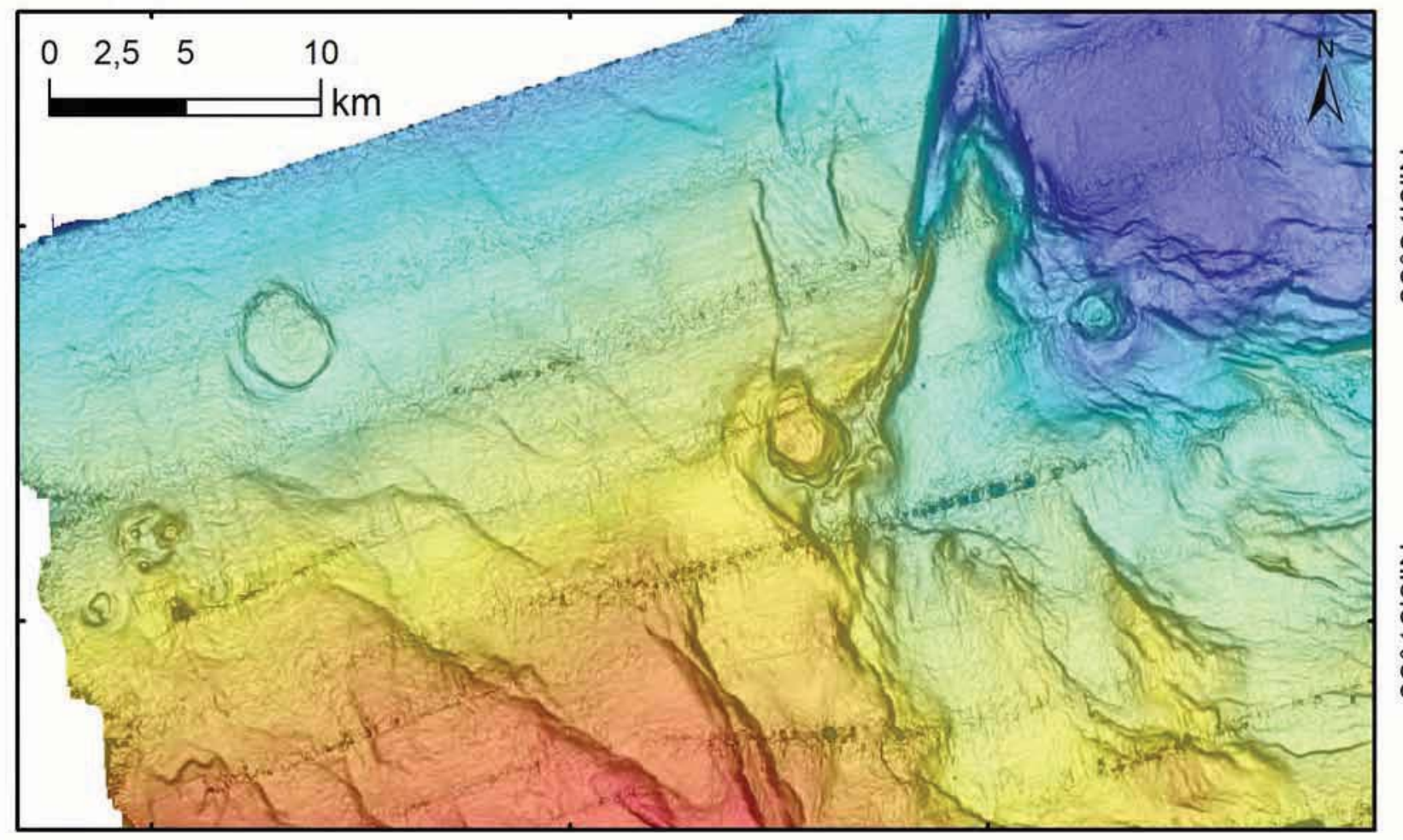

b)

$31^{\circ} 30^{\prime} 0 " \mathrm{E}$

$31^{\circ} 40^{\prime} 0 " \mathrm{E}$

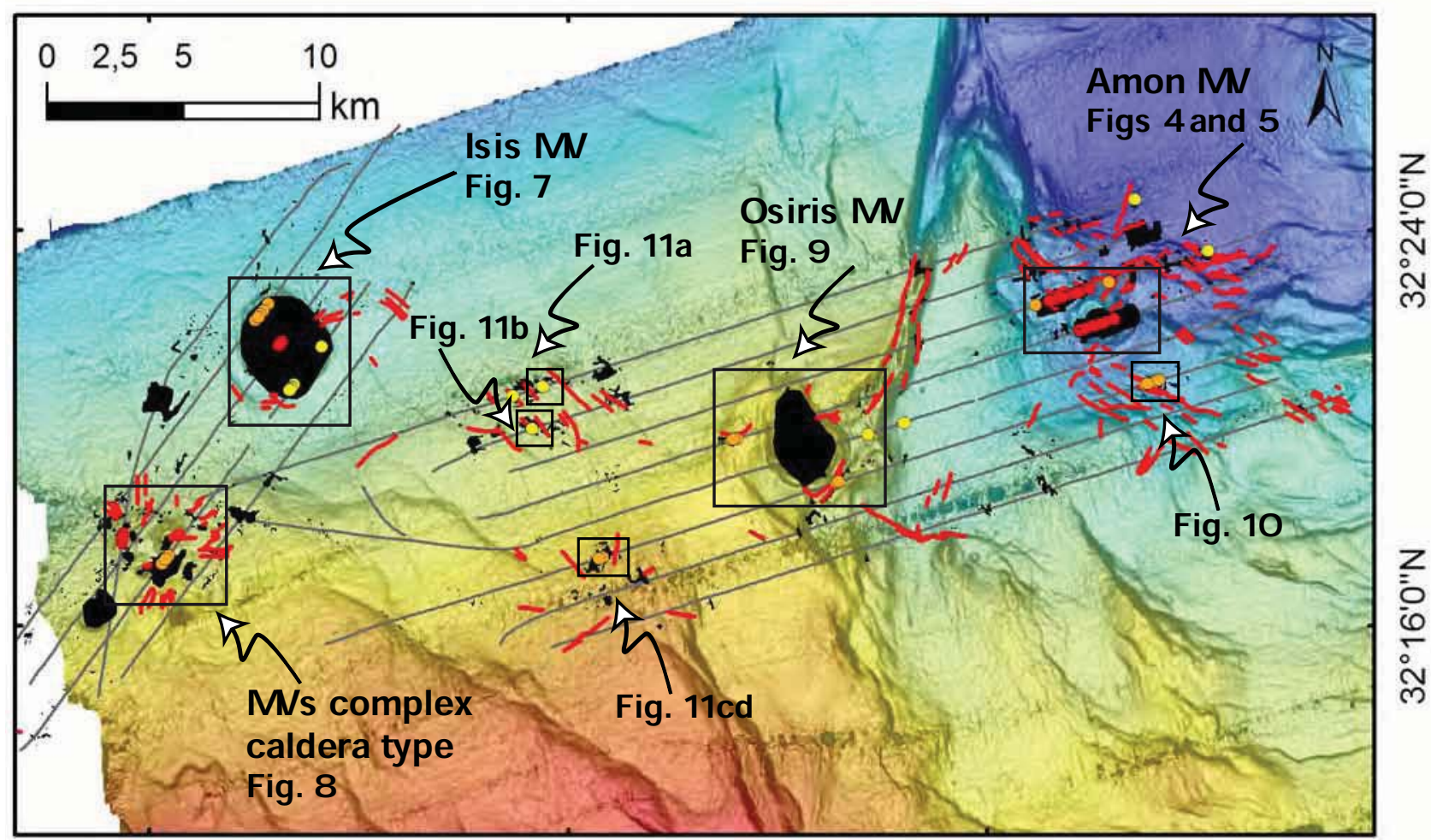

Side scan sonar EdgeTech 75 kHz (Mimes 2004)

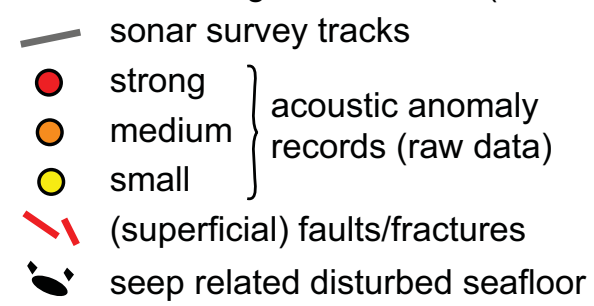

Bathymetry EM300 30 kHz (Fanil 2000) Sardou and Mascle (2003)

$437 \quad 1528$ metres

$z$
בे
సे
సे

2
0
0
0
$\stackrel{0}{\circ}$ 
a)

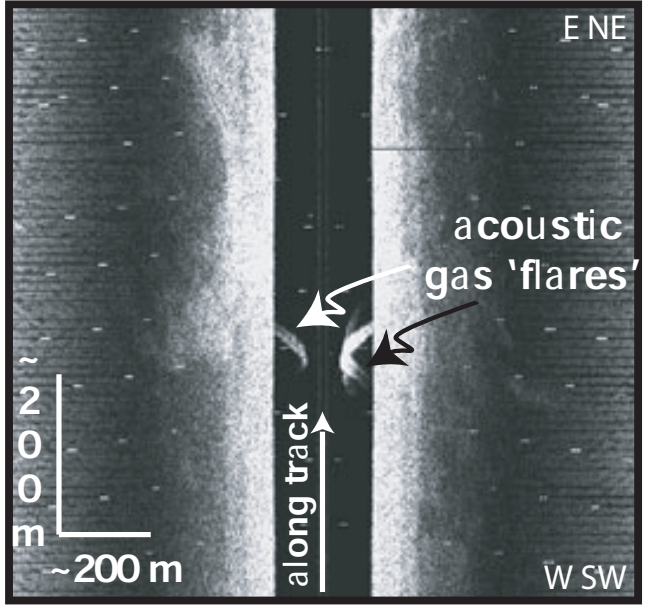

Backscatter amplitude (dB)

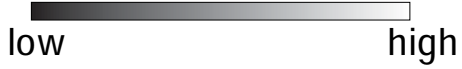

b)

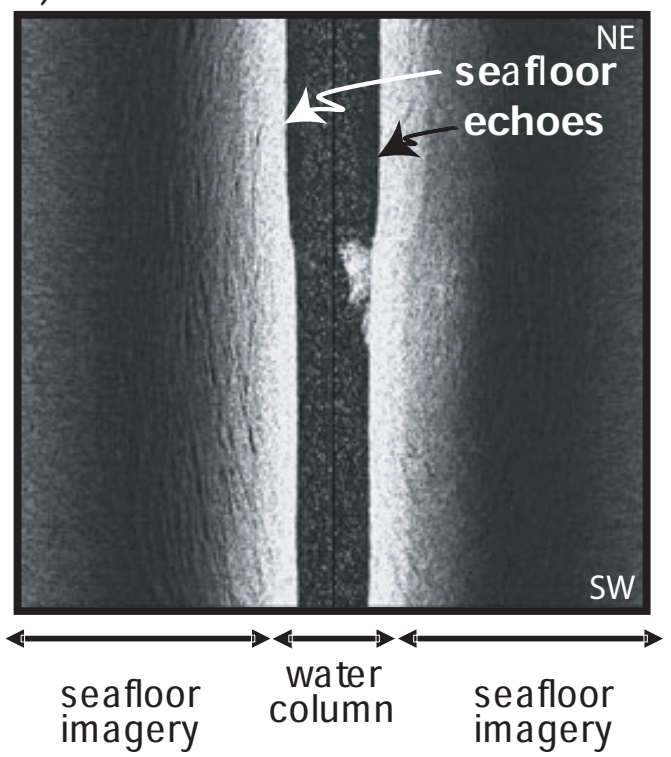

c)

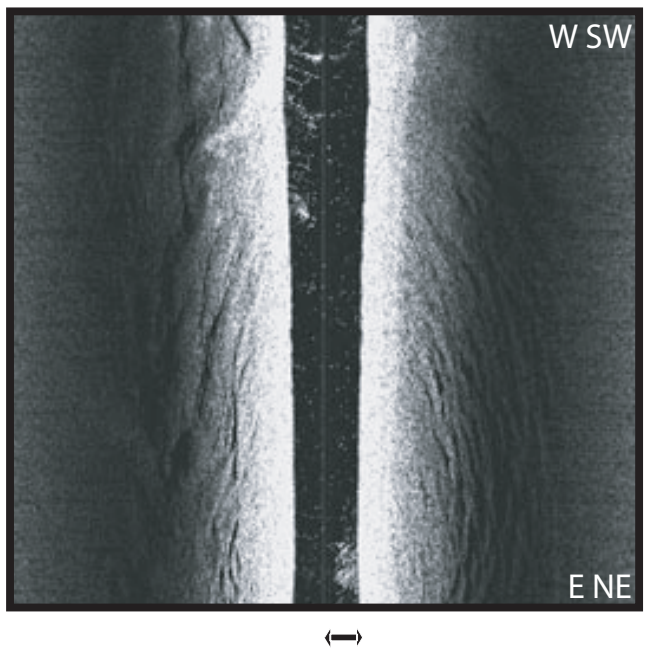

vehicle

elevation d)

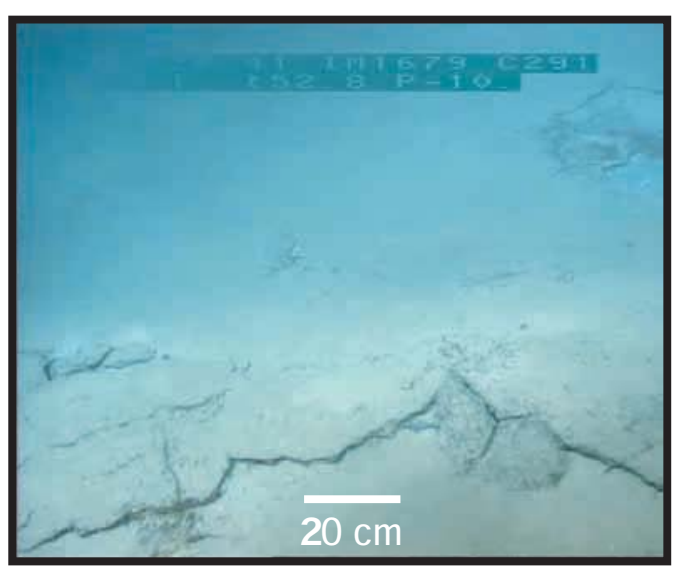

e)

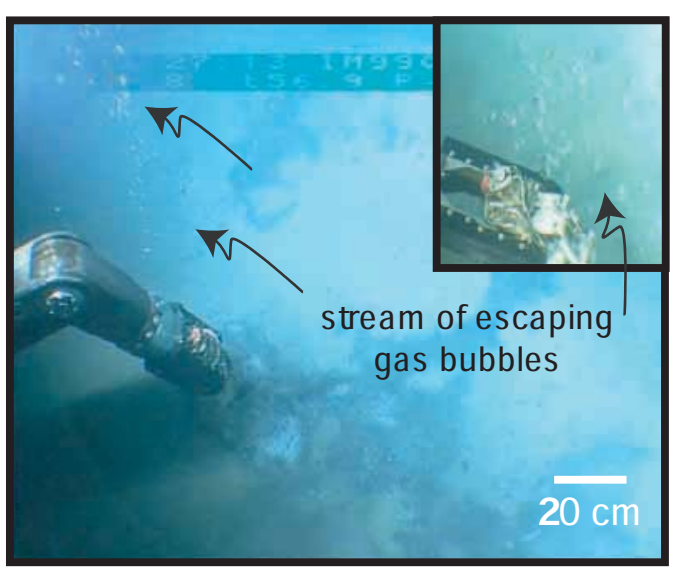

f)

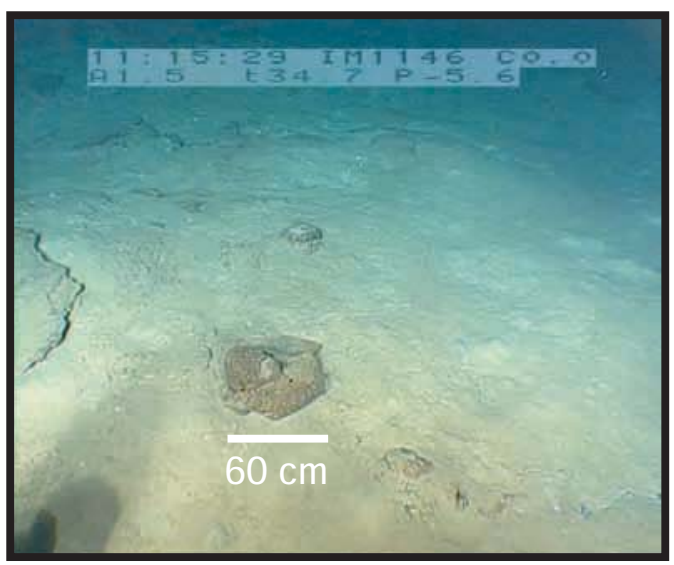


a)

$31^{\circ} 41^{\prime} 24^{\prime \prime}$

$31^{\circ} 42^{\prime} 0^{\prime \prime E}$

$31^{\circ} 42^{\prime} 36^{\prime \prime E}$

$31^{\circ} 43^{\prime} 12^{\prime \prime E}$

$31^{\circ} 43^{\prime} 48^{\prime \prime} \mathrm{E}$

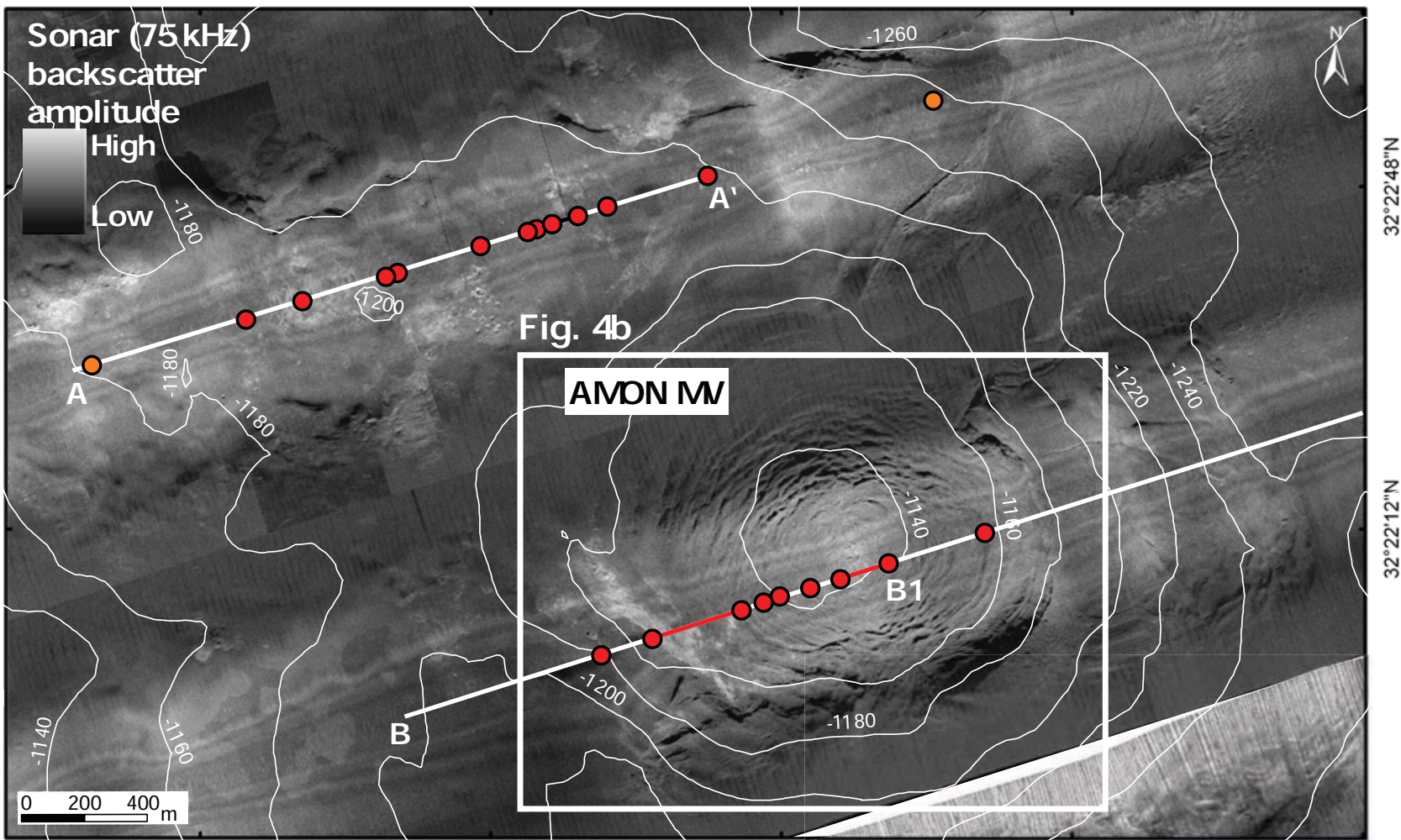

b)

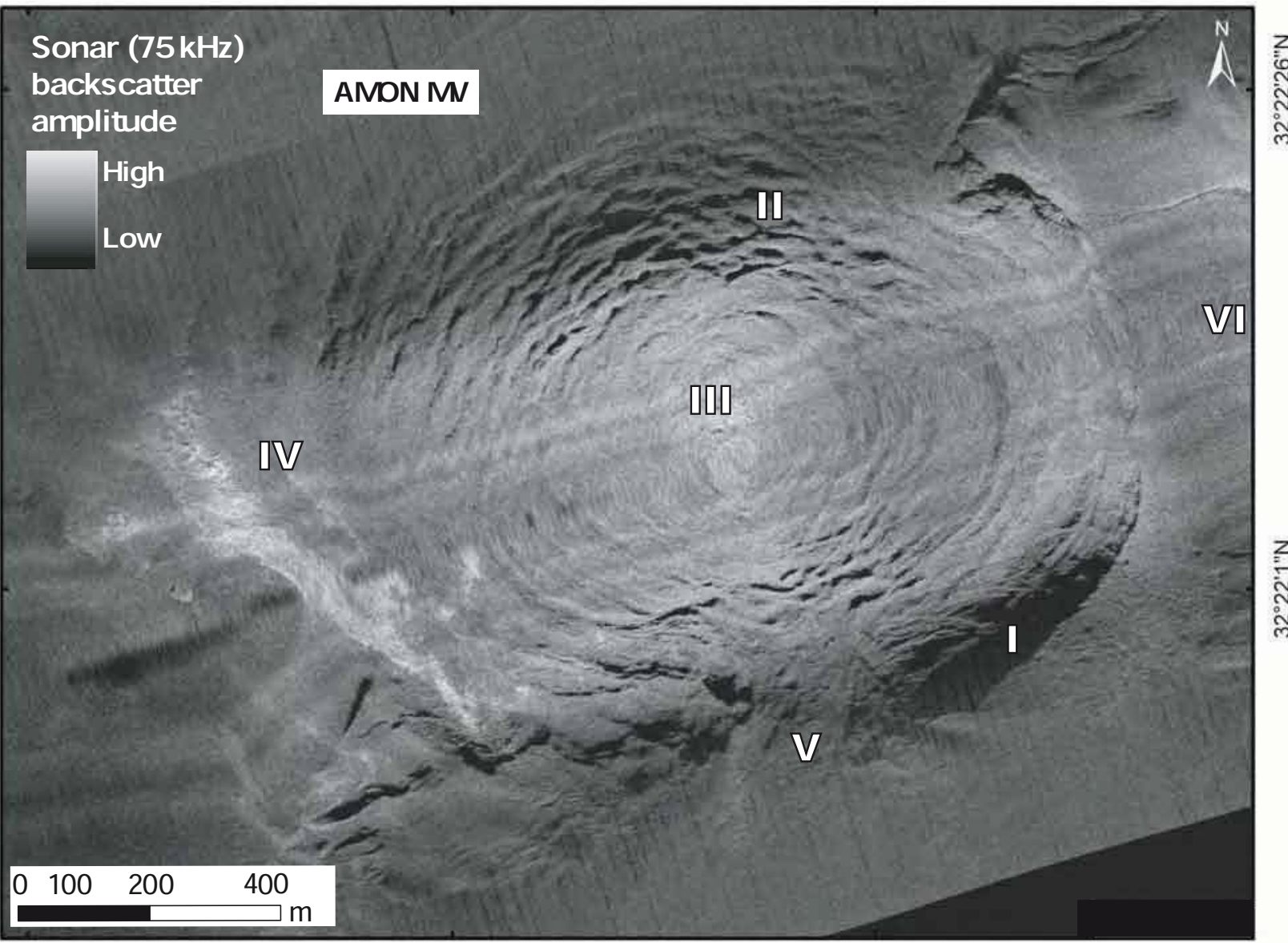



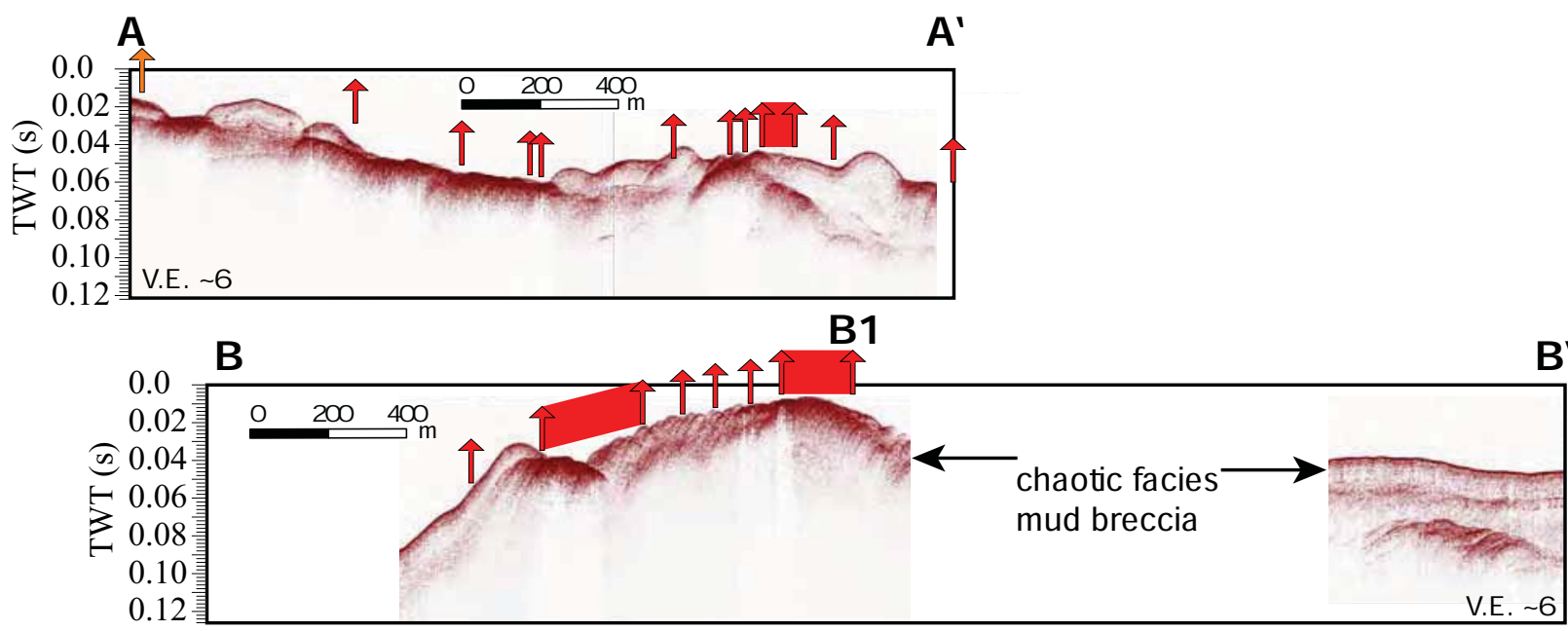

\section{Legend}

Strong and large water column acoustic anomalies (raw data, see e.g. Figs. 3a and b)

Medium water column acoustic anomalies (raw data)

Small water column acoustic anomalies recorded (raw data, see e.g. Fig. 3c)

\begin{tabular}{|c|c|c|}
\hline & mosaic & profile \\
\hline locally & 0 & 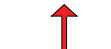 \\
\hline along a distance & 0 & \\
\hline locally & 0 & \\
\hline along a distance & 00 & \\
\hline locally & 0 & 个 \\
\hline along a distance & 00 & \\
\hline
\end{tabular}




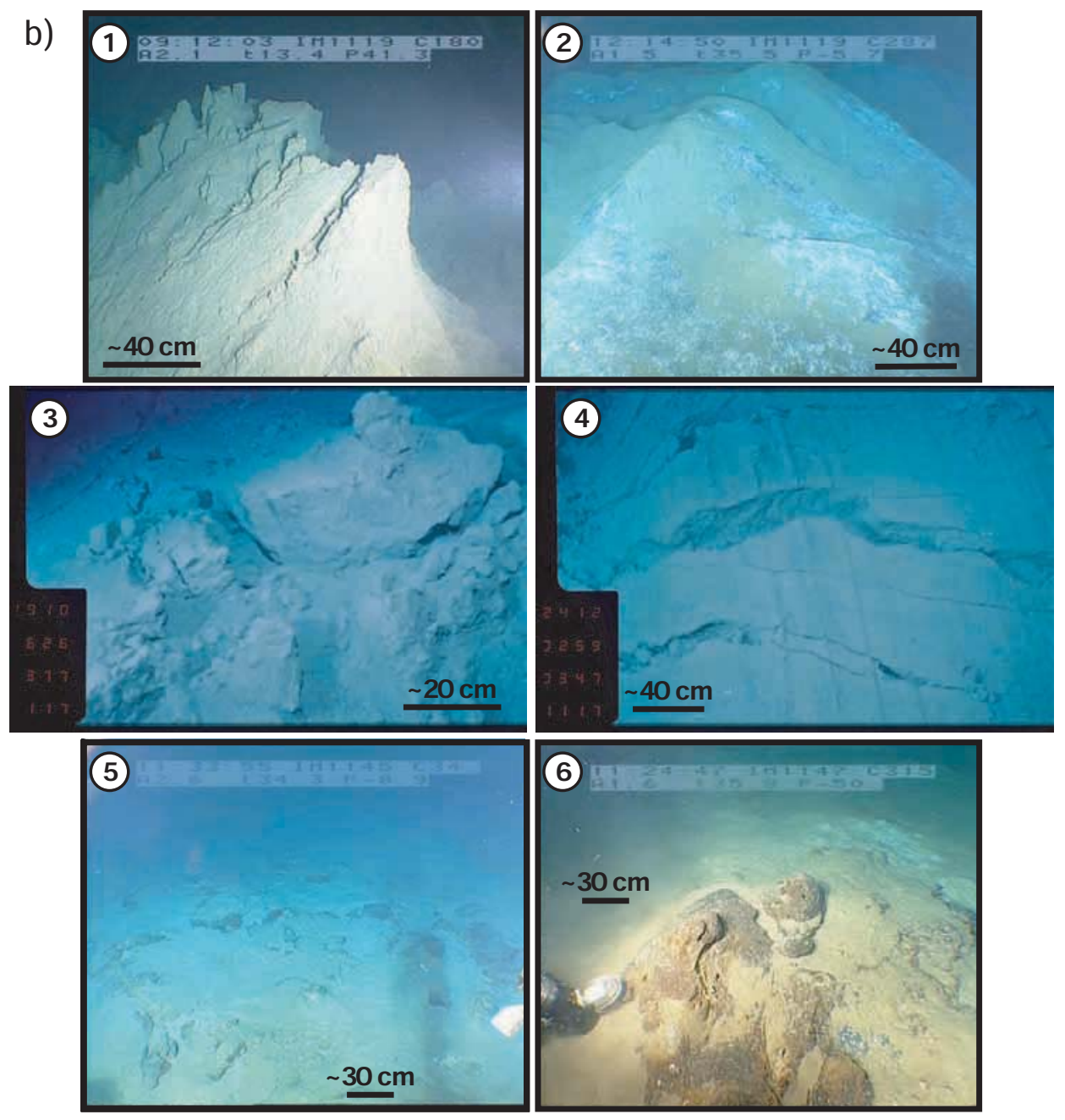


a)

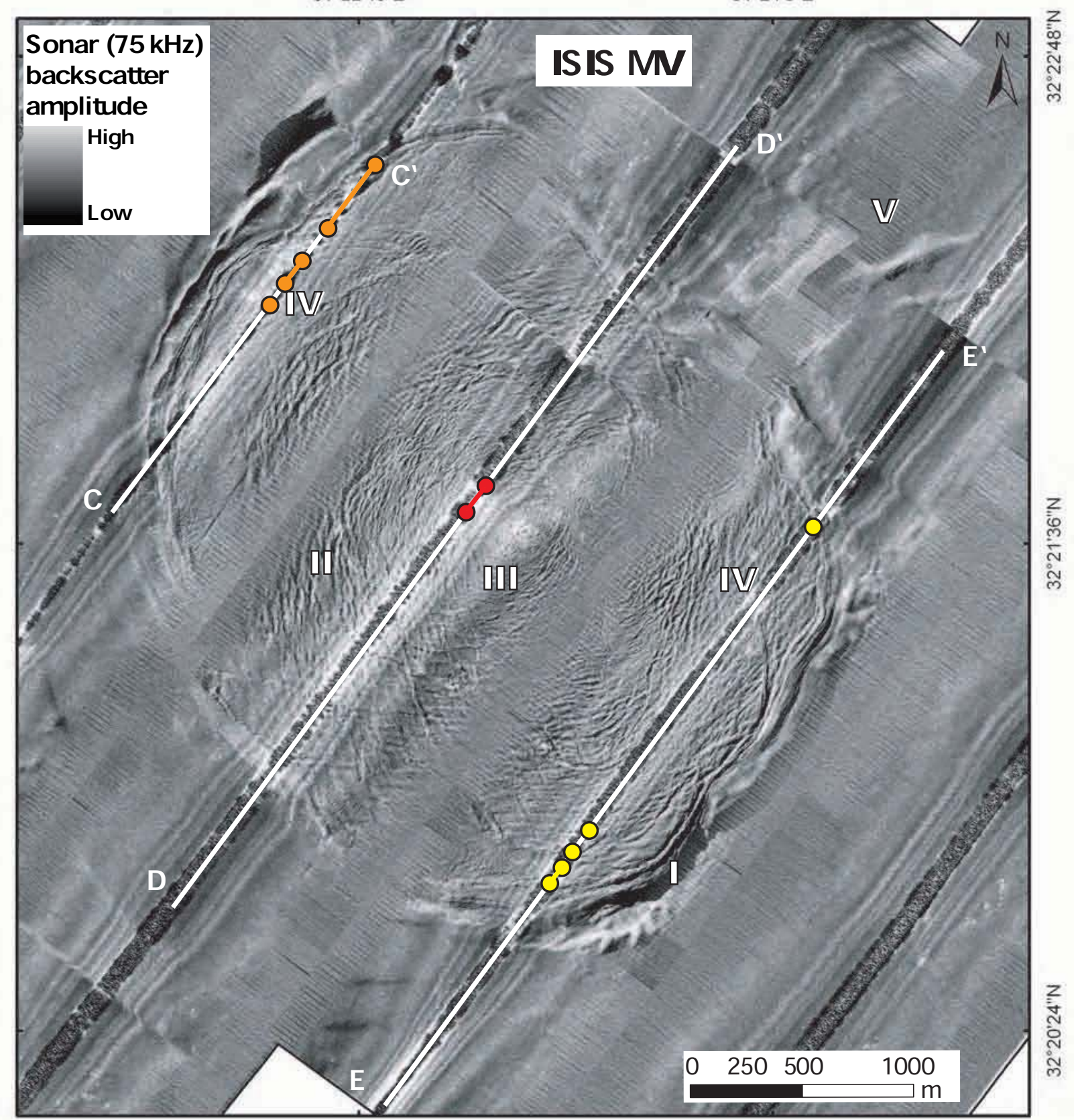

b)
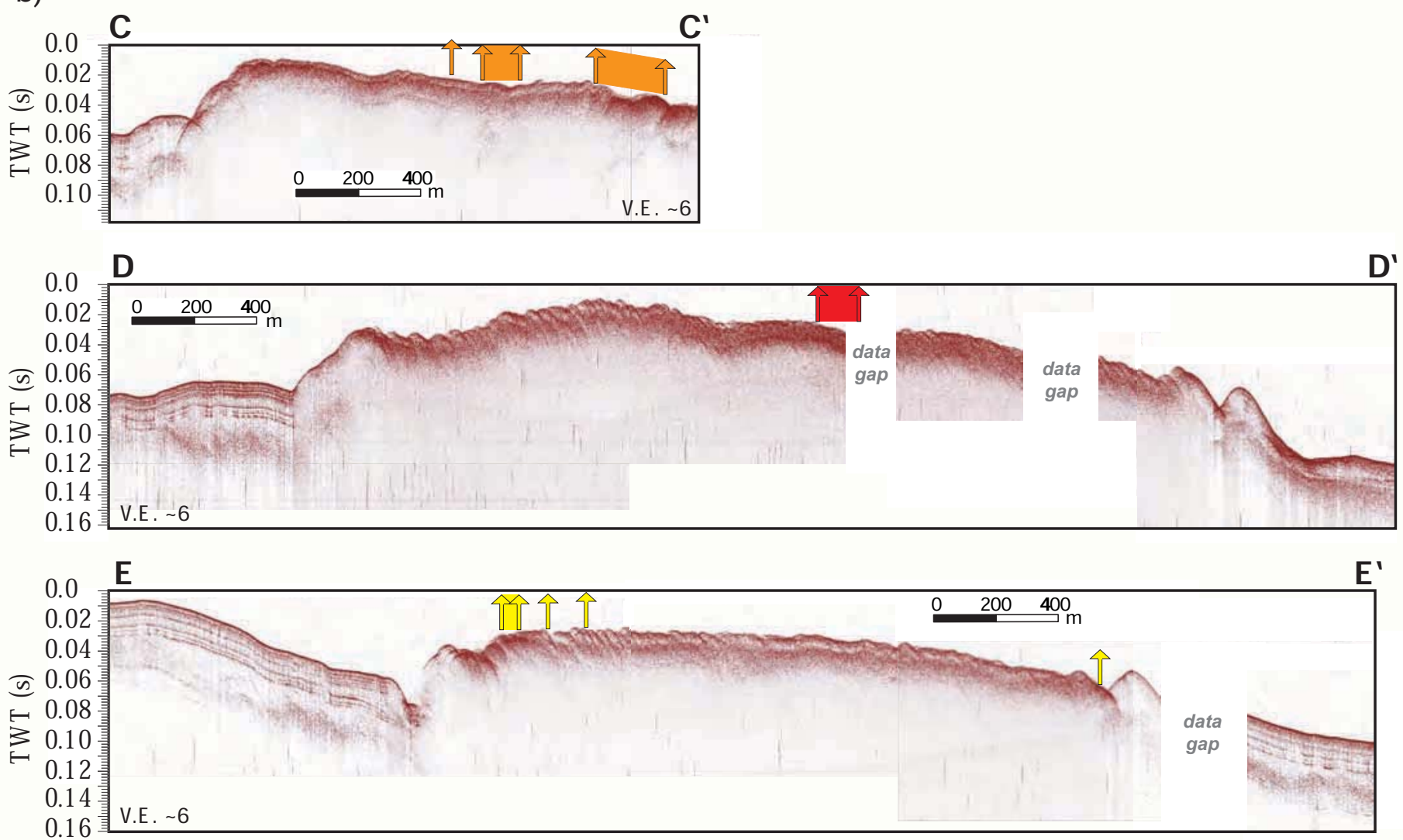
a)
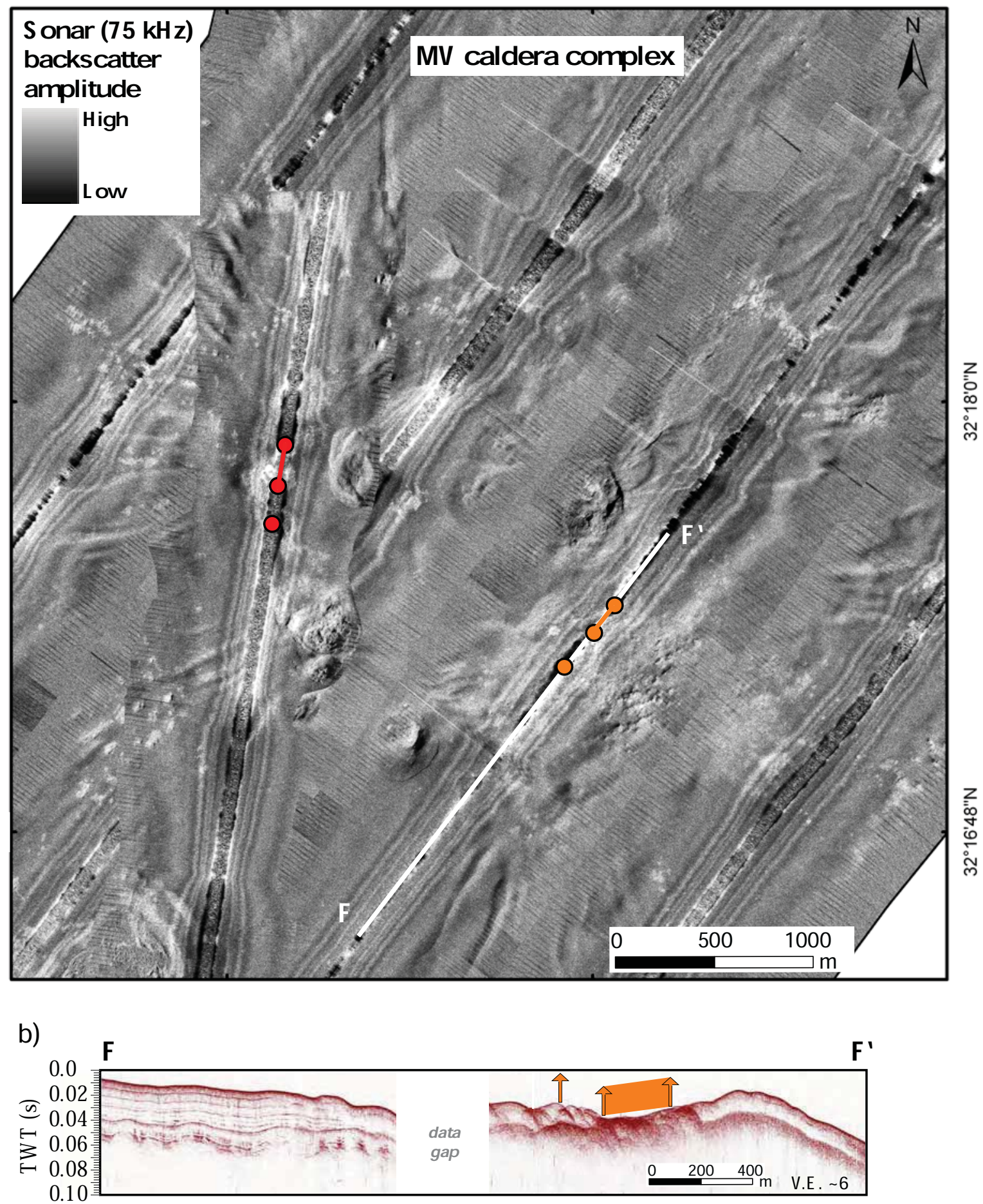

c)

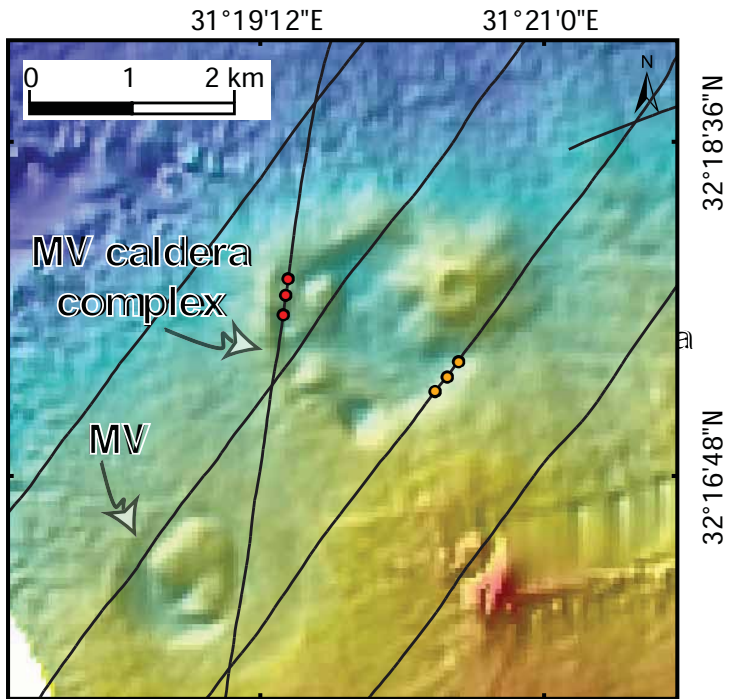

Bathymetry - E M300 $30 \mathrm{kHz}$ (F anil 2000) S ardou and Mascle (2003)

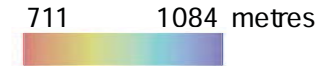

\section{Chirp profile tracks} 2-8 kHz (Mimes 2004) 
a)
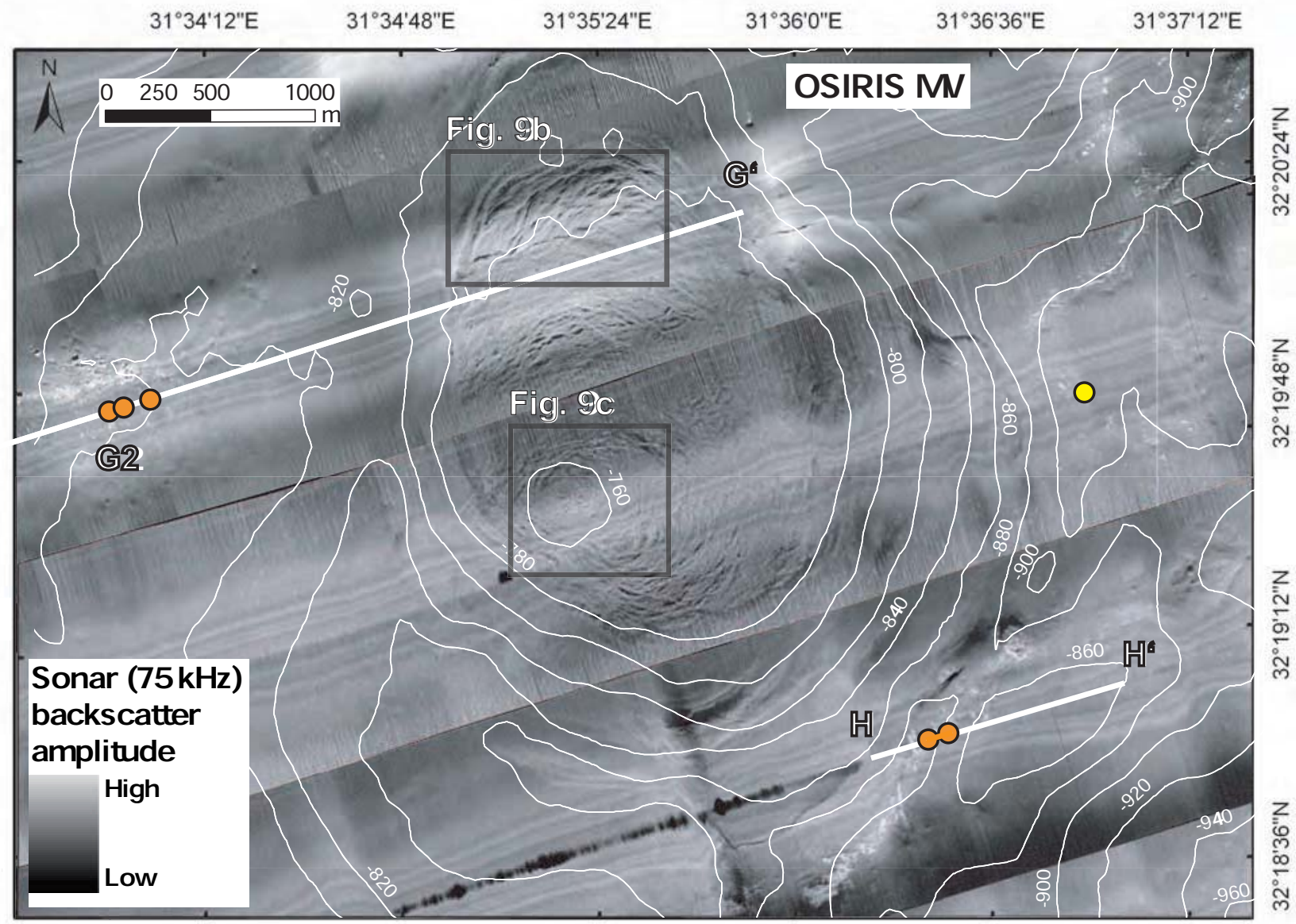

b)

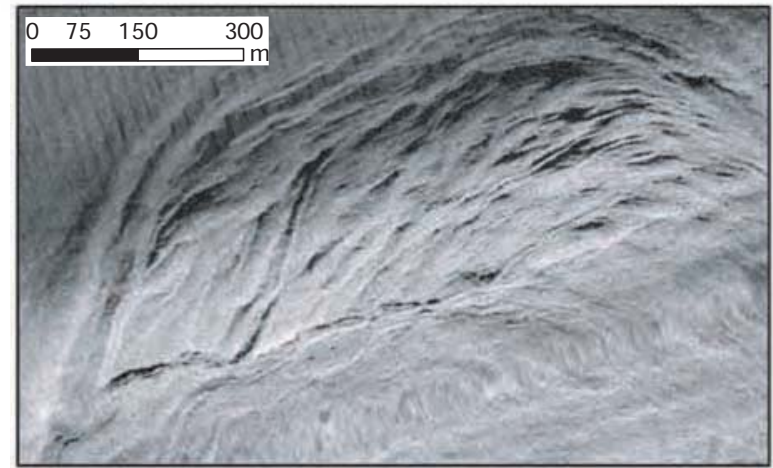

C)

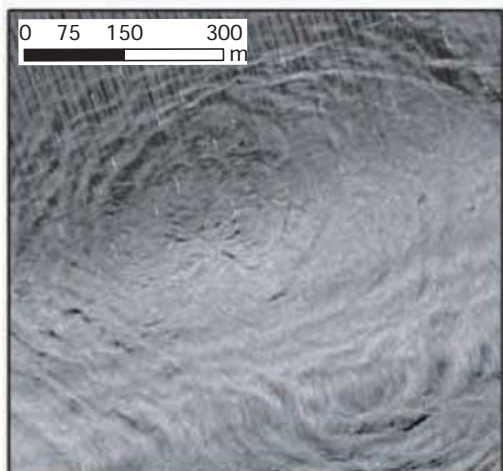

d)

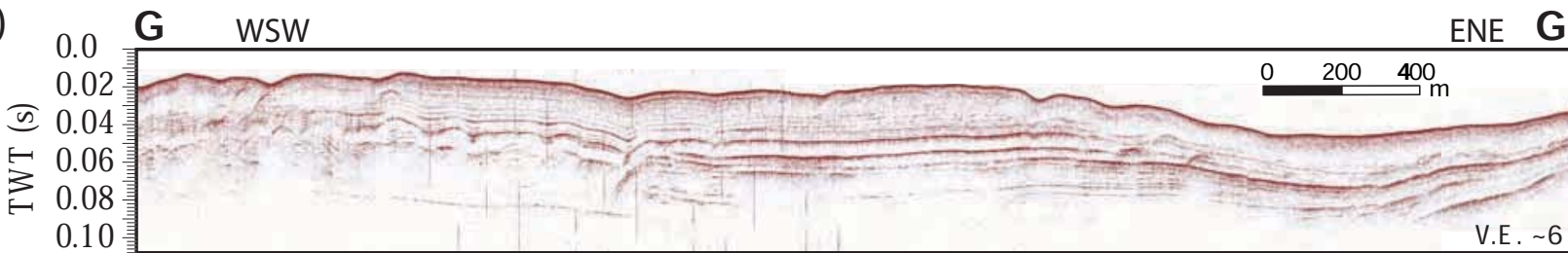

ENE G1
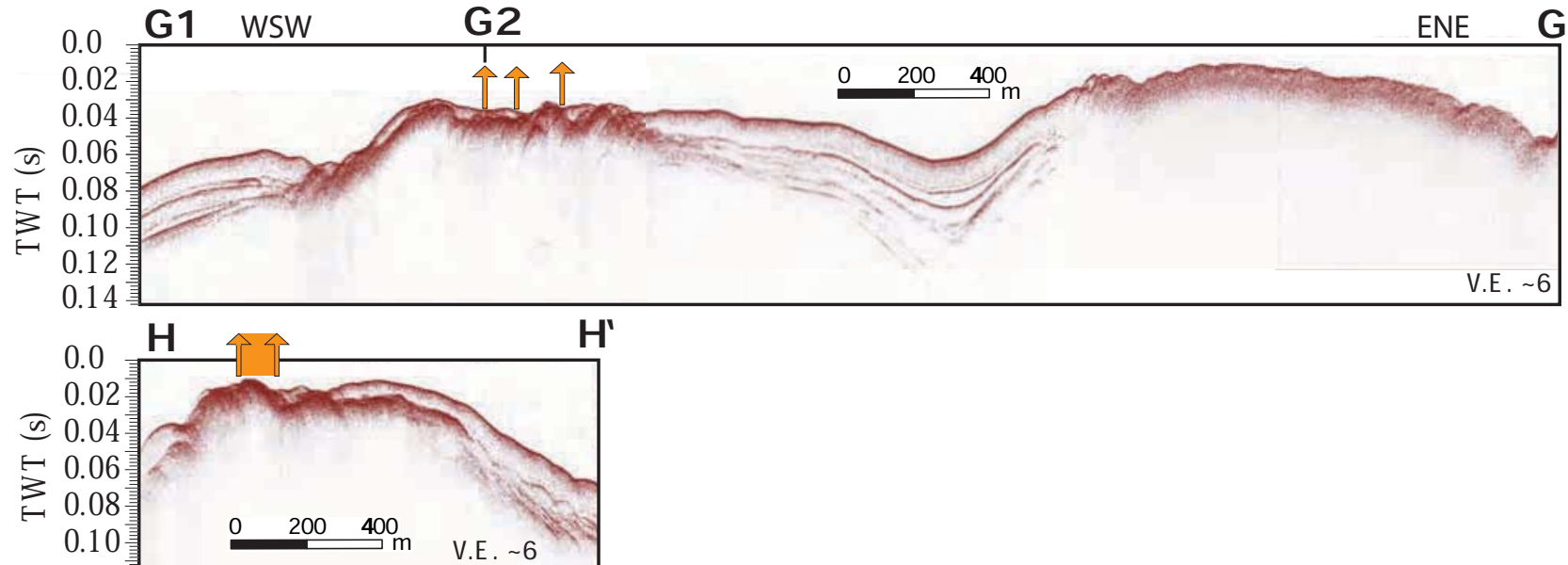


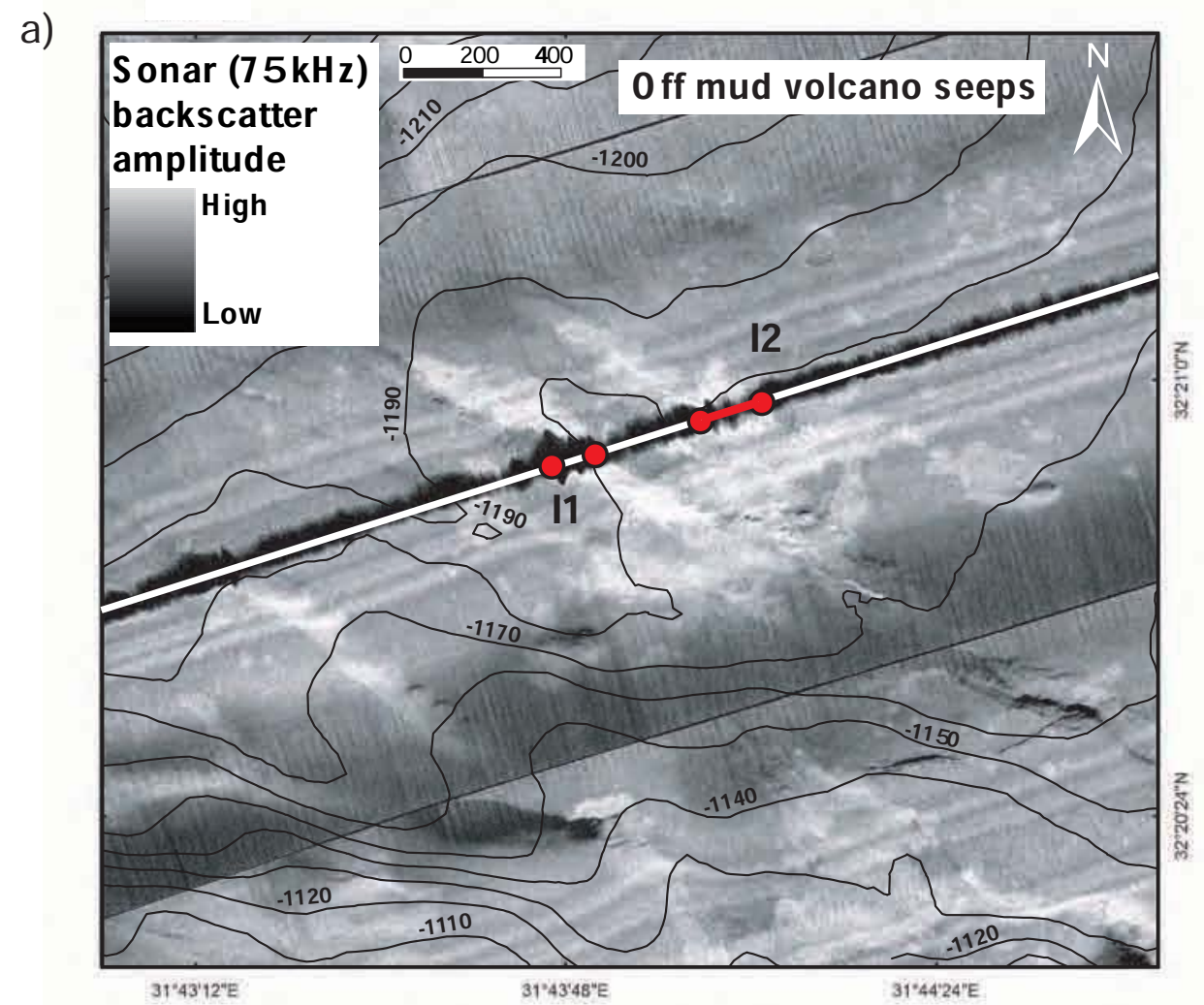

b)

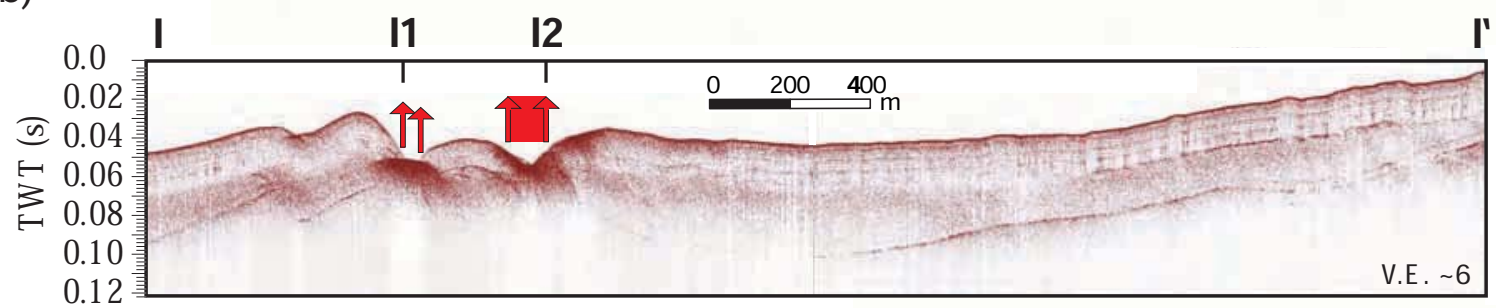



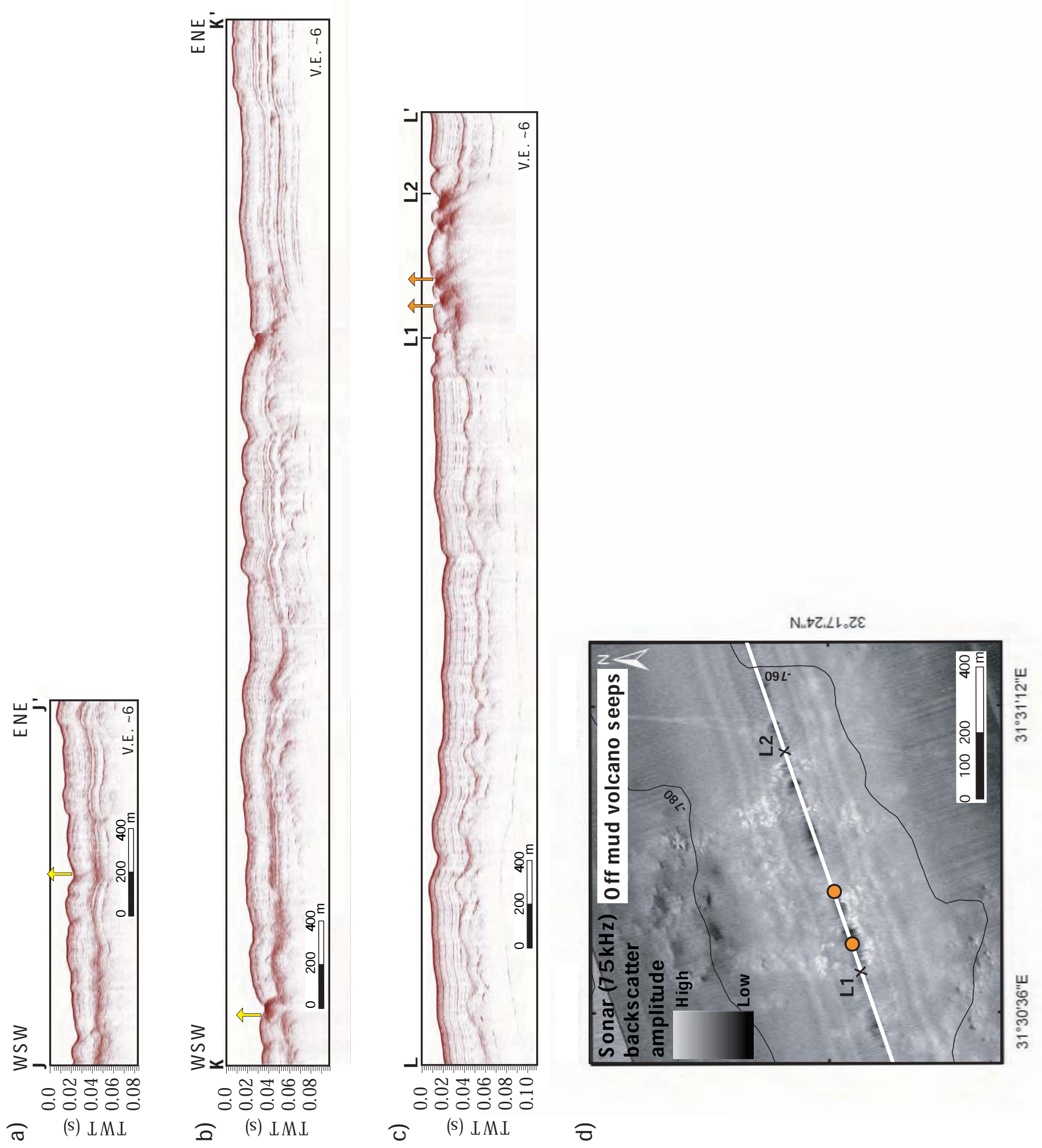
a) Sonar (75 kHz) backscatter amplitude

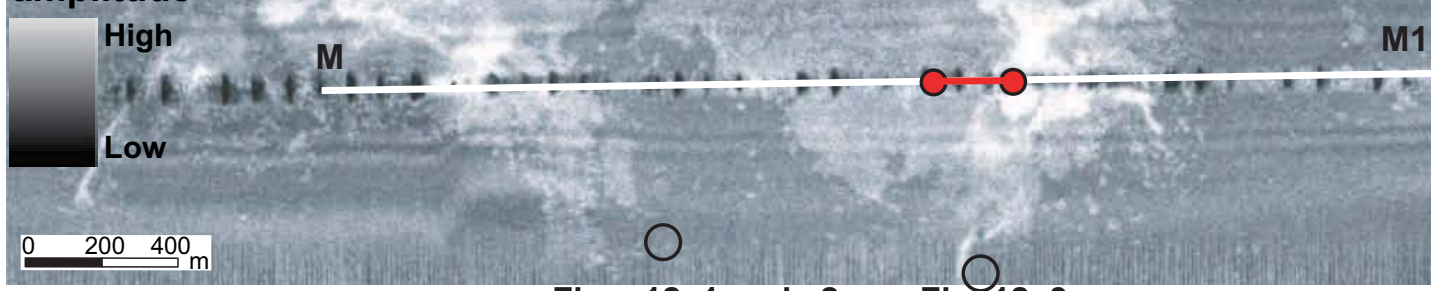

Figs. 12c1 and c2 Fig. 12c3

b)

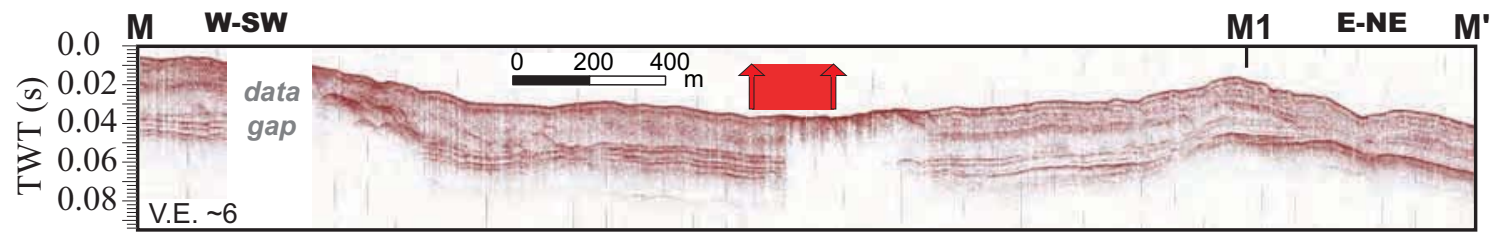

c)

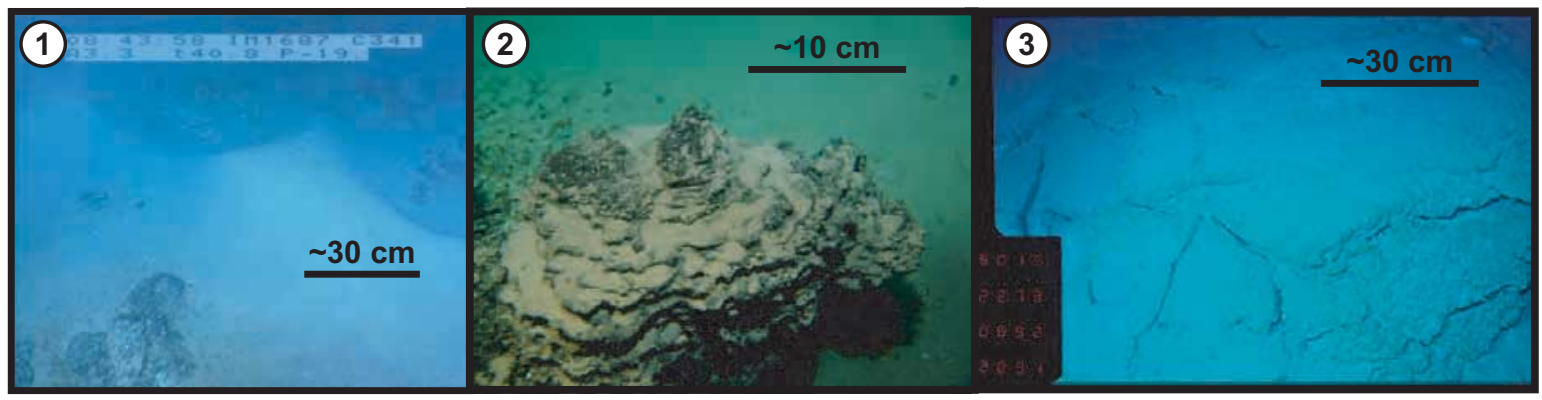




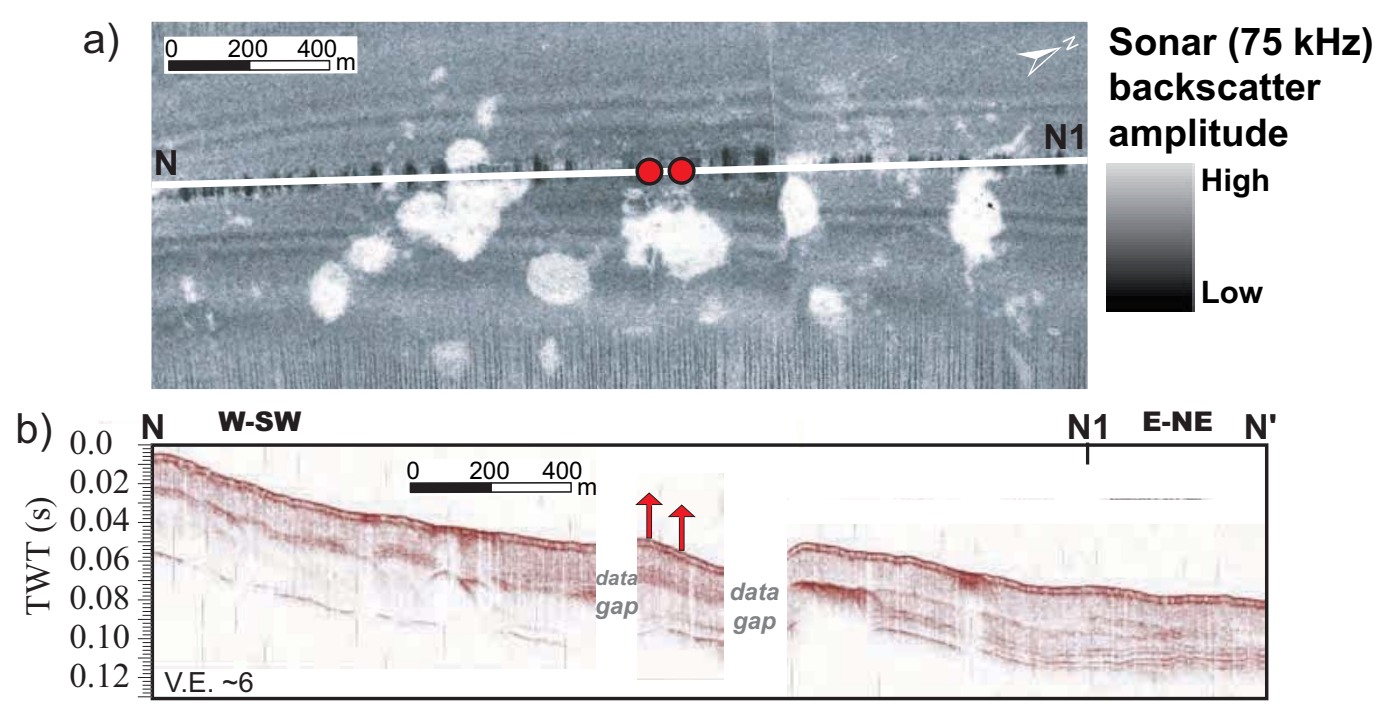

